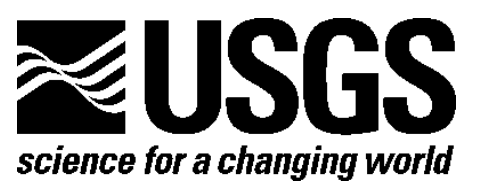

\title{
Hurricane Sandy: Observations and Analysis of Coastal Change
}

By Kristin L. Sopkin, Hilary F. Stockdon, Kara S. Doran, Nathaniel G. Plant, Karen L. M. Morgan, Kristy K. Guy, and Kathryn E. L. Smith

Open-File Report 2014-1088

U.S. Department of the Interior

U.S. Geological Survey 


\section{U.S. Department of the Interior \\ SALLY JEWELL, Secretary}

\section{U.S. Geological Survey \\ Suzette M. Kimball, Acting Director}

U.S. Geological Survey, Reston, Virginia: 2014

For more information on the USGS-the Federal source for science about the Earth,
its natural and living resources, natural hazards, and the environment-visit
http://www.usgs.gov or call 1-888-ASK-USGS (1-888-275-8747)
For an overview of USGS information products, including maps, imagery, and publications,
visit http://www.usgs.gov/pubprod

To order this and other USGS information products, visit http://store.usgs.gov

Any use of trade, firm, or product names is for descriptive purposes only and does not imply endorsement by the U.S. Government.

Although this information product, for the most part, is in the public domain, it also may contain copyrighted materials as noted in the text. Permission to reproduce copyrighted items must be secured from the copyright owner.

Suggested citation:

Sopkin, K.L., Stockdon, H.F., Doran, K.S., Plant, N.G., Morgan, K.L.M., Guy, K.K., and Smith, K.E.L., 2014, Hurricane Sandy-Observations and Analysis of Coastal Change: U.S. Geological Survey Open-File Report 20141088, 54 p., http://dx.doi.org/10.3133/ofr20141088.

ISSN 2331-1258 (online) 


\section{Contents}

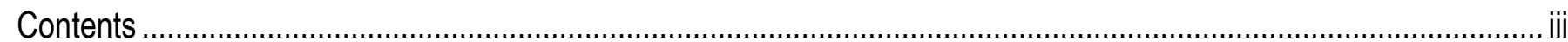

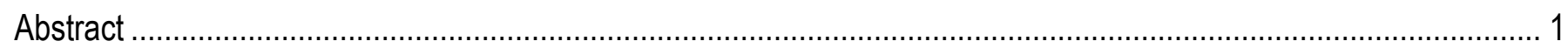

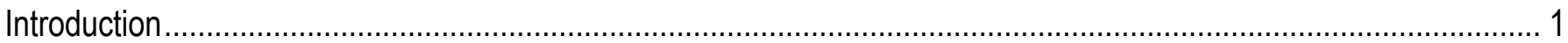

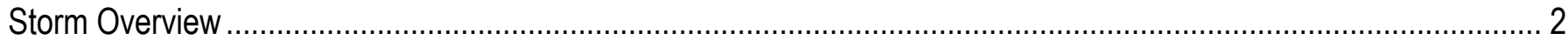

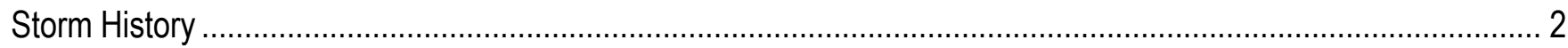

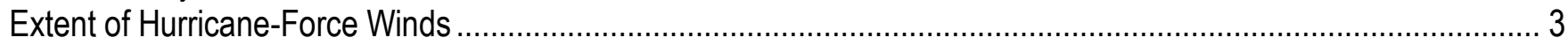

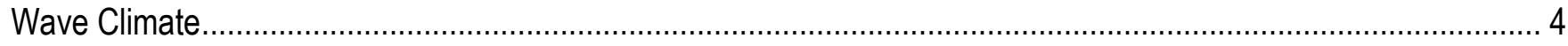

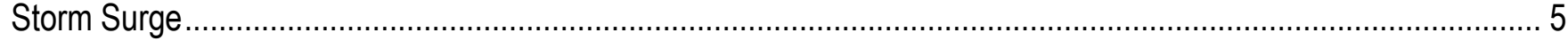

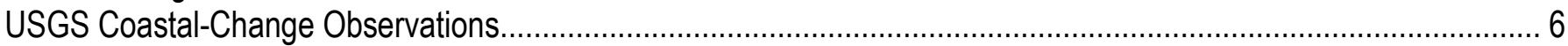

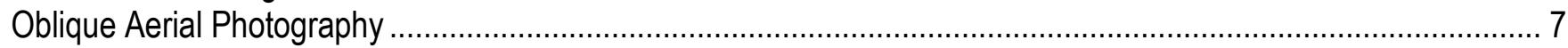

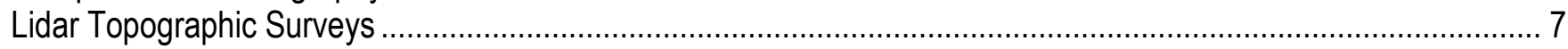

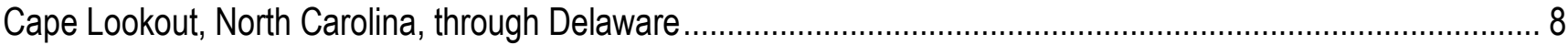

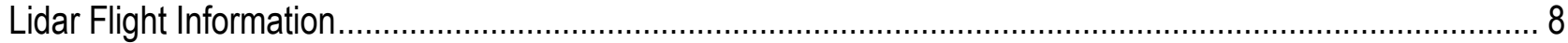

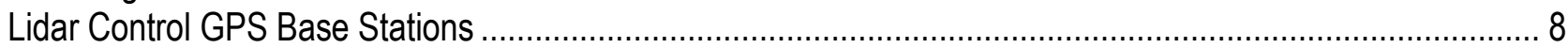

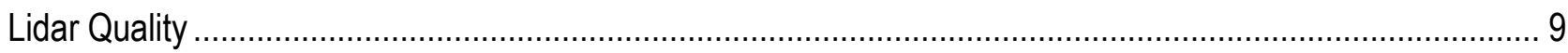

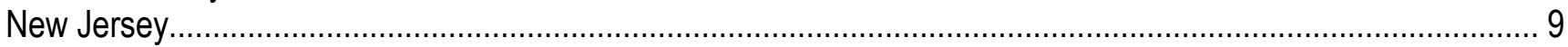

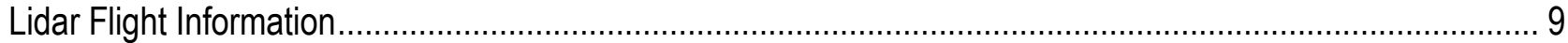

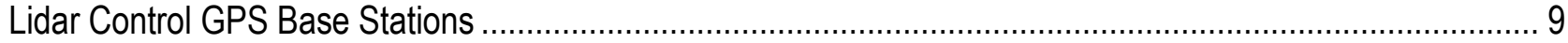

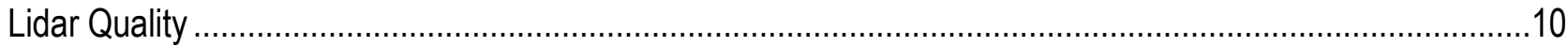

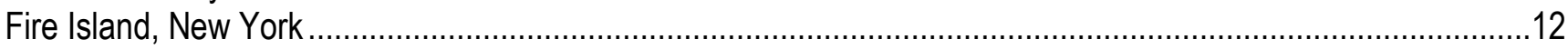

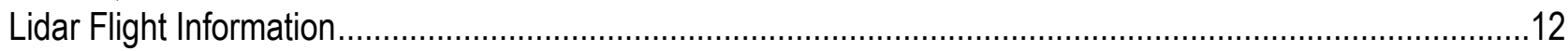

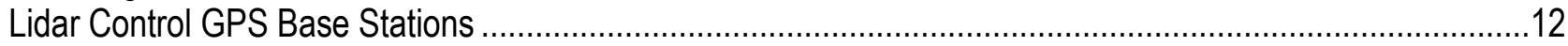

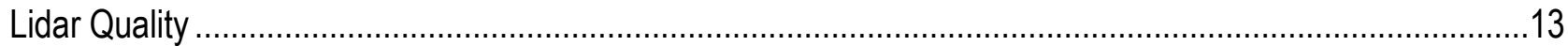

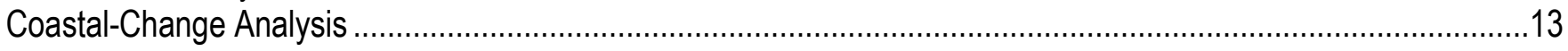

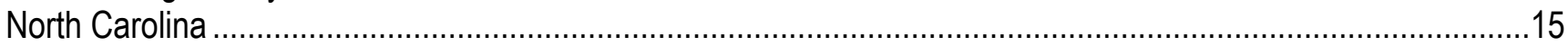

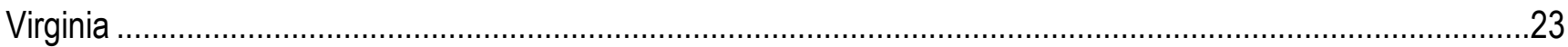

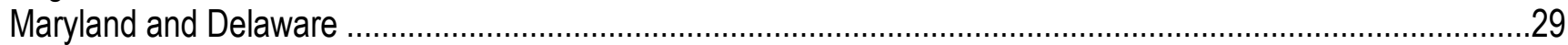

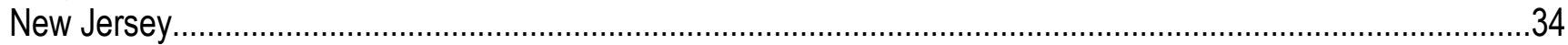

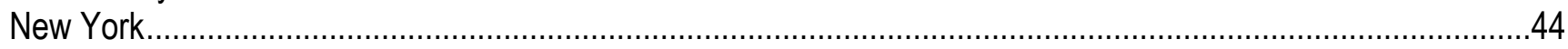

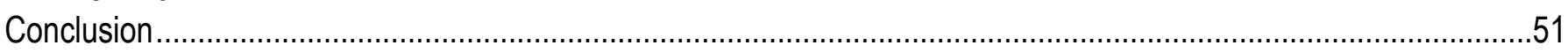

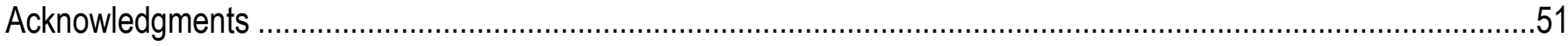

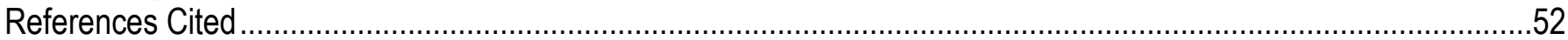




\section{Figures}

1. Hurricane Sandy track and intensity... 3

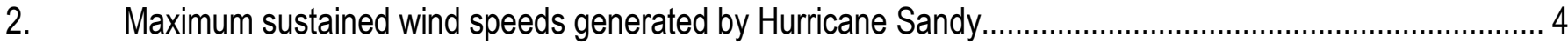

3. Significant wave height during the passage of Hurricane Sandy ……................................................. 5

4. Pre- and post-Hurricane Sandy aerial photography, lidar coverage, and GPS base station locations............. 6

5. Hurricane Sandy lidar relative offset evaluation location for USGS pre- and post-storm EAARL-B lidar surveys and post-storm ground-based survey area

6. November 1, 2012, EAARL-B first-return lidar elevations versus NJBPN transect elevations measured November 1, 2012

7. August 2010 CHARTS last-return lidar elevations versus October 2012 EAARL-B and November 2012

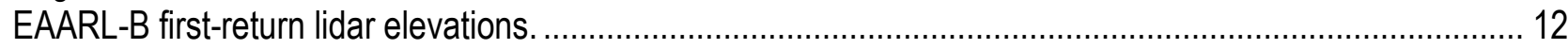

8. Map of location index for photo pairs and pre- and post-Hurricane Sandy lidar comparisons ........................ 14

9. Hurricane Sandy dune-elevation change, shoreline change, and beach-volume change between August 2009 and November 2012 for the North Carolina barrier-island coast.

10. North Carolina location 1: oblique aerial photographs of Rodanthe, N.C., from August 30, 2011, and November 4, 2012

11. Three-dimensional view of Rodanthe, Kinnakeet, North Carolina, lidar-based topography measured postNor'lda 2009 and post-Hurricane Sandy November 2012

12. North Carolina location 2: oblique aerial photographs of Pea Island National Wildlife Refuge, Kinnakeet, N.C., from August 30, 2011, and November 4, 2011.

13. Three-dimensional view of Pea Island National Wildlife Refuge, Kinnakeet, North Carolina, lidar-based topography measured post-Nor'Ida 2009 and post-Hurricane Sandy November 2012.

14. Hurricane Sandy dune-elevation change, shoreline change, and beach-volume change between November 2009 and November 2012 for the Virginia coast.

15. Virginia location 3: oblique aerial photographs of Virginia's barrier-island shore from May 21, 2009, and November 6, 2012

16. Virginia location 4: oblique aerial photographs of Assateague Island, Virginia, from May 21, 2009, and November 6, 2012

17. Three-dimensional view of Chincoteague National Wildlife Refuge, Assateague Island, Virginia, lidar-based topography measured post-Nor'Ida 2009 and post-Hurricane Sandy November 2012.

18. Hurricane Sandy dune-elevation change, shoreline change, and beach-volume change between September 2010 and November 2012 for the Maryland and Delaware coasts

19. Maryland/Delaware location 5: oblique aerial photographs of Assateague Island, Maryland, from May 21, 2009, and November 6, 2012

20. Three-dimensional view of Assateague Island, Maryland, lidar-based topography measured post-Nor'Ida 2009 and post-Hurricane Sandy November 2012.

21. Maryland/Delaware location 6: oblique aerial photographs of South Bethany, Delaware, from May 21, 2009, and November 6, 2012.

22. Hurricane Sandy dune-elevation change, shoreline change, and beach-volume change between October and November 2012 for the New Jersey coast. 
23. New Jersey location 7: oblique aerial photographs of Brigantine, New Jersey, from May 21, 2009, and November 5, 2012

24. Three-dimensional view of Brigantine, New Jersey, lidar-based topography measured October 2012 and post-Hurricane Sandy November 2012.

25. New Jersey location 8: oblique aerial photographs of Island Beach State Park, New Jersey, from May 21, 2009, and November 5, 2012

26. New Jersey location 9: oblique aerial photographs of Seaside Heights, New Jersey, from May 21, 2009, and November 5, 2012.

27. Three-dimensional view of Seaside Heights, New Jersey, lidar-based topography measured October 2012 and post-Hurricane Sandy November 2012

28. New Jersey location 10: oblique aerial photographs of Mantoloking, New Jersey, from May 21, 2009, and November 5, 2012

29. Three-dimensional view of Mantoloking, New Jersey, lidar-based topography measured October 2012 and post-Hurricane Sandy November 2012.

30. Hurricane Sandy dune-elevation change, shoreline change, and beach-volume change between May and November 2012 for the Fire Island, New York, coast and between August 2010 and November 2012 for the rest of Long Island, New York.

31. New York location 11: oblique aerial photographs of Neponsit, New York, from May 21, 2009, and November 5, 2012.

32. New York location 12: oblique aerial photographs of Ocean Bay Park, Fire Island, New York, from May 21, 2009, and November 5, 2012.

33. Three-dimensional view of Ocean Bay Park, Fire Island, New York, lidar-based topography measured May 2012 and post-Hurricane Sandy November 2012.

34. New York location 13: oblique aerial photographs of Pelican Island and Fire Island, New York, from May 21, 2009, and November 5, 2012. 49

35. Three-dimensional view of Pelican Island and Fire Island, New York, lidar-based topography measured May 2012 and post-Hurricane Sandy November 2012. 


\section{Tables}

1. Details of the pre-Hurricane Sandy photography collection. .............................................................. 7

2. Details of the pre-Hurricane Sandy lidar data used for coastal-change analysis.

3. Details of autonomous GPS control stations used during the November $5-29,2012$, contract lidar mission.... 8

4. Details of the GPS control station used during the October 26, 2012, and November 1-5, 2012, U.S.

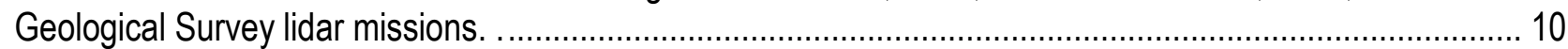

5. Details of the GPS control station used during the November 5, 2012, contract lidar survey mission of Fire

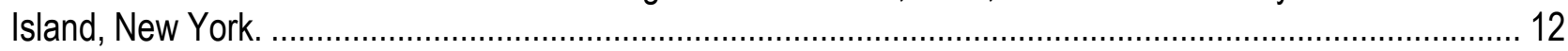

6. Details of the mean-high-water line used for coastal-change analysis. .................................................... 15 


\section{Conversion Factors}

International System of Units to Inch/Pound

\begin{tabular}{|c|c|c|}
\hline Multiply & By & To obtain \\
\hline \multicolumn{3}{|c|}{ Length } \\
\hline centimeter $(\mathrm{cm})$ & 0.3937 & inch (in.) \\
\hline millimeter (mm) & 0.03937 & inch (in.) \\
\hline meter $(\mathrm{m})$ & 3.281 & foot (ft) \\
\hline kilometer (km) & 0.6214 & mile (mi) \\
\hline kilometer (km) & 0.5400 & mile, nautical (nmi) \\
\hline meter (m) & 1.094 & yard (yd) \\
\hline \multicolumn{3}{|c|}{ Area } \\
\hline square meter $\left(\mathrm{m}^{2}\right)$ & 0.0002471 & acre \\
\hline square kilometer $\left(\mathrm{km}^{2}\right)$ & 247.1 & acre \\
\hline square meter $\left(\mathrm{m}^{2}\right)$ & 10.76 & square foot $\left(\mathrm{ft}^{2}\right)$ \\
\hline square kilometer $\left(\mathrm{km}^{2}\right)$ & 0.3861 & square mile $\left(\mathrm{mi}^{2}\right)$ \\
\hline \multicolumn{3}{|c|}{ Volume } \\
\hline cubic meter $\left(\mathrm{m}^{3}\right)$ & 35.31 & cubic foot $\left(\mathrm{ft}^{3}\right)$ \\
\hline cubic meter $\left(\mathrm{m}^{3}\right)$ & 1.308 & cubic yard $\left(\mathrm{yd}^{3}\right)$ \\
\hline \multicolumn{3}{|c|}{ Flow rate } \\
\hline kilometer per hour $(\mathrm{km} / \mathrm{h})$ & 0.6214 & mile per hour $(\mathrm{mi} / \mathrm{h})$ \\
\hline kilometer per hour $(\mathrm{km} / \mathrm{h})$ & 0.5400 & knots (kt) \\
\hline
\end{tabular}

\section{Datum}

Vertical coordinate information is referenced to the North American Vertical Datum of 1988 (NAVD 88).

Horizontal coordinate information is referenced to the North American Datum of 1983 (NAD 83). 


\section{Abbreviations}

\begin{tabular}{|c|c|}
\hline ACRONYM OR ABBREVIATION & DEFINITION \\
\hline CHARTS & Compact Hydrographic Airborne Rapid Total Survey \\
\hline CORS & Continuously Operating Reference Stations \\
\hline DEM & Digital Elevation Model \\
\hline DFL & Distance From Landfall \\
\hline EAARL & Experimental Advanced Airborne Research Lidar \\
\hline GPS & Global Positioning System \\
\hline $\mathrm{Hz}$ & Hertz \\
\hline $\mathrm{kHz}$ & Kilohertz \\
\hline KISP & Long Island MacArthur Airport \\
\hline KMFV & Accomack County Airport \\
\hline KMRH & Michael J. Smith Field Airport \\
\hline KSBY & Salisbury-Ocean City Wicomico Regional Airport \\
\hline kts & Knots \\
\hline Lidar & Light Detection and Ranging \\
\hline $\mathrm{NACCH}$ & National Assessment of Coastal Change Hazards \\
\hline NAD 83 & North American Datum 1983 \\
\hline NAVD 88 & North American Vertical Datum 1988 \\
\hline NHC & National Hurricane Center \\
\hline NDBC & National Data Buoy Center \\
\hline NOAA & National Oceanic and Atmospheric Administration \\
\hline NWC & National Weather Center \\
\hline NWS & National Weather Service \\
\hline USACE & U.S. Army Corps of Engineers \\
\hline
\end{tabular}


USGS

UTC

WGS84
U.S. Geological Survey

Universal Time Coordinated

World Geodetic System 1984 


\title{
Hurricane Sandy: Observations and Analysis of Coastal Change
}

By Kristin L. Sopkin, Hilary F. Stockdon, Kara S. Doran, Nathaniel G. Plant, Karen L. M. Morgan, Kristy K. Guy and Kathryn E. L. Smith

\begin{abstract}
Hurricane Sandy, the largest Atlantic hurricane on record, made landfall on October 29, 2012, and impacted a long swath of the U.S. Atlantic coastline. The barrier islands were breached in a number of places and beach and dune erosion occurred along most of the Mid-Atlantic coast. As a part of the National Assessment of Coastal Change Hazards project, the U.S. Geological Survey collected postHurricane Sandy oblique aerial photography and lidar topographic surveys to document the changes that occurred as a result of the storm. Comparisons of post-storm photographs to those collected prior to Sandy's landfall were used to characterize the nature, magnitude, and spatial variability of hurricaneinduced coastal changes. Analysis of pre- and post-storm lidar elevations was used to quantify magnitudes of change in shoreline position, dune elevation, and beach width. Erosion was observed along the coast from North Carolina to New York; however, as would be expected over such a large region, extensive spatial variability in storm response was observed.
\end{abstract}

\section{Introduction}

The U.S. Geological Survey (USGS) National Assessment of Coastal Change Hazards (NACCH) project (http://coastal.er.usgs.gov/national-assessment) provides hazard information to those concerned about the Nation's coastlines, including residents of coastal areas, government agencies responsible for coastal management, and coastal researchers. One such hazard is extreme storms. Hurricanes, nor'easters, and Pacific winter storms are powerful events that generate dangerous waves and surge capable of moving large amounts of sand, destroying buildings and infrastructure, and even taking lives. Through processes like dune erosion, overwash, and inundation, storms reshape our nation's coastline. The "storm impacts" component of NACCH (http://coastal.er.usgs.gov/hurricanes) focuses on understanding the magnitude and variability of extreme storm impacts on sandy beaches. The overall objective is to improve real-time and scenario-based predictions of coastal change to support management of coastal infrastructure, resources, and safety.

Understanding storm-induced coastal change and forecasting these changes requires knowledge of the physical processes associated with a storm and the geomorphology of the impacted coastline. The primary physical process of interest is sediment transport driven by waves, currents, and the storm surge associated with storms. Storm surge, which is a rise in water level due to the wind, barometric pressure, and other factors, allows both waves and currents to impact parts of the coast not normally exposed to these processes. Coastal geomorphology — sand dune elevation, beach width, and beach slope - reflects the changes driven by these processes during extreme storms. These variables, in addition to the hydrodynamic processes, can be used to quantify coastal change, understand the coastal response to storms, and predict vulnerability to erosion during future storms. 
A critical part of this work is direct observation of the impacts of storms on beaches. Immediately following hurricane landfall, the USGS responds with a large data-collection effort that includes oblique aerial photography, airborne topographic surveys, and ground-based topographic surveys. This report documents the USGS data-collection efforts in response to the October 29, 2012, landfall of Hurricane Sandy near Brigantine, N.J. Qualitative observations and an initial quantitative analysis of hurricane-induced changes to the shoreline, beaches, and dunes are presented for the region most heavily impacted by the storm. Additional research, outside the scope of this report, will focus on the reasons behind the spatial variation in the observed response.

The remainder of this report is divided into the following sections:

- Storm Overview - presents a synopsis of the storm, including meteorological evolution, wind speed impact area, wind-wave generation, and storm surge extent and magnitudes.

- Coastal-Change Observations - describes data-collection missions, including acquisition of oblique aerial photography and airborne light detection and ranging (lidar) topographic surveys, and observations of coastal change in response to Hurricane Sandy.

- Coastal-Change Analysis - describes data-analysis methods and results.

\section{Storm Overview}

\section{Storm History}

Hurricane Sandy was an active tropical weather system in the Caribbean Sea and the North Atlantic Ocean from October 22 to October 29, 2012 (fig. 1; Blake and others, 2013). On October 22 at 1200 Universal Time Coordinated (UTC), a convective band associated with an area of low pressure located 565 kilometers $(\mathrm{km})$ south-southwest of Kingston, Jamaica, became organized enough to be classified as a tropical depression. At 1800 UTC the same day, Tropical Storm Sandy became the 18th named storm of the 2012 hurricane season. Sandy strengthened to hurricane status at 1200 UTC on October 24 approximately $148 \mathrm{~km}$ south of Jamaica and made landfall in Jamaica as a Category 1 (75 knot (kt)) hurricane at 1900 UTC that same day. Hurricane Sandy intensified to a Category 3 hurricane before making a subsequent landfall near Santiago de Cuba, Cuba, on October 25 at 0525 UTC. After passage over eastern Cuba, the hurricane slowed and turned to the northwest, skirting the Bahamas and edging the east coast of Great Abaco Island before briefly weakening to below hurricane strength and curving to the north. On October 27 at 1200 UTC, Sandy regained hurricane intensity. Approximately $407 \mathrm{~km}$ southeast of Atlantic City, N.J., after encountering colder air and the cooler water of the northwest Atlantic Ocean, Sandy transitioned to an extratropical cyclone at 2100 UTC on October 29. Post-Tropical Cyclone Sandy made landfall near Brigantine, N.J., with maximum sustained winds of 130 kilometers per hour $(\mathrm{km} / \mathrm{h})(70 \mathrm{kt})$ on October 29, 2012, at $2330 \mathrm{UTC}$. 

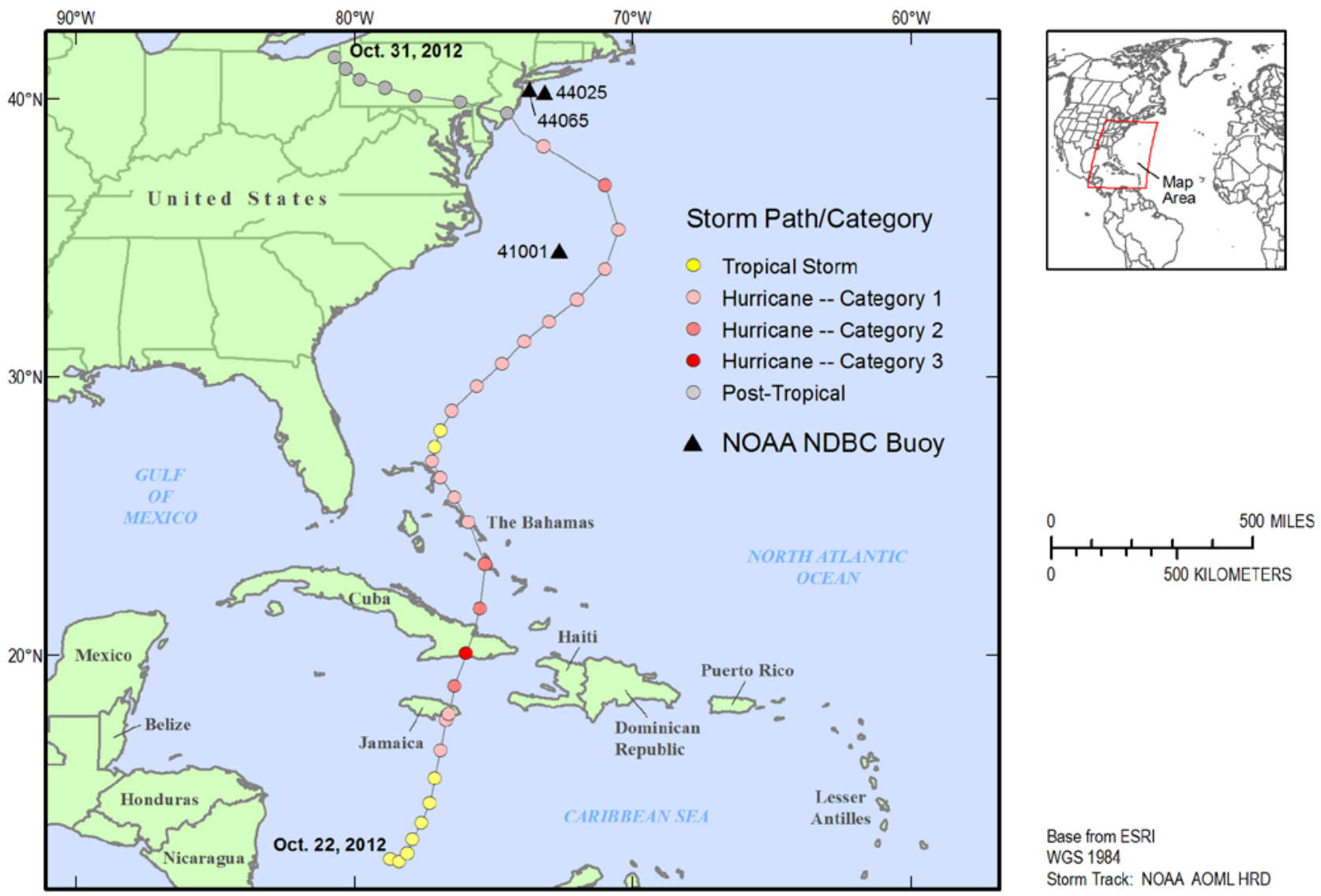

Base from ESRI

WGS 1984

Storm Track: NOAA AOML HRD

Figure 1. Hurricane Sandy track and intensity and moored National Oceanic and Atmospheric Administration, National Data Buoy Center (NDBC) buoys recording wave height and period.

\section{Extent of Hurricane-Force Winds}

Based on the maximum sustained winds estimated by the National Oceanic and Atmospheric Administration (NOAA) Atlantic Oceanographic and Meteorological Laboratory Hurricane Research Division (using methods described by Powell and others, 1998), hurricane-force winds from Hurricane Sandy impacted approximately $80 \mathrm{~km}$ of the New Jersey coastline between Townsends Inlet and Surf City (fig. 2). Sandy was an extremely large storm with tropical storm-force winds reaching from Wallops Island, Va., to Montauk, N.Y., at the time of landfall (Blake and others, 2013). Along the path of the storm, tropical storm-force winds affected most of the U.S. Atlantic coastline, from Florida to Maine. 

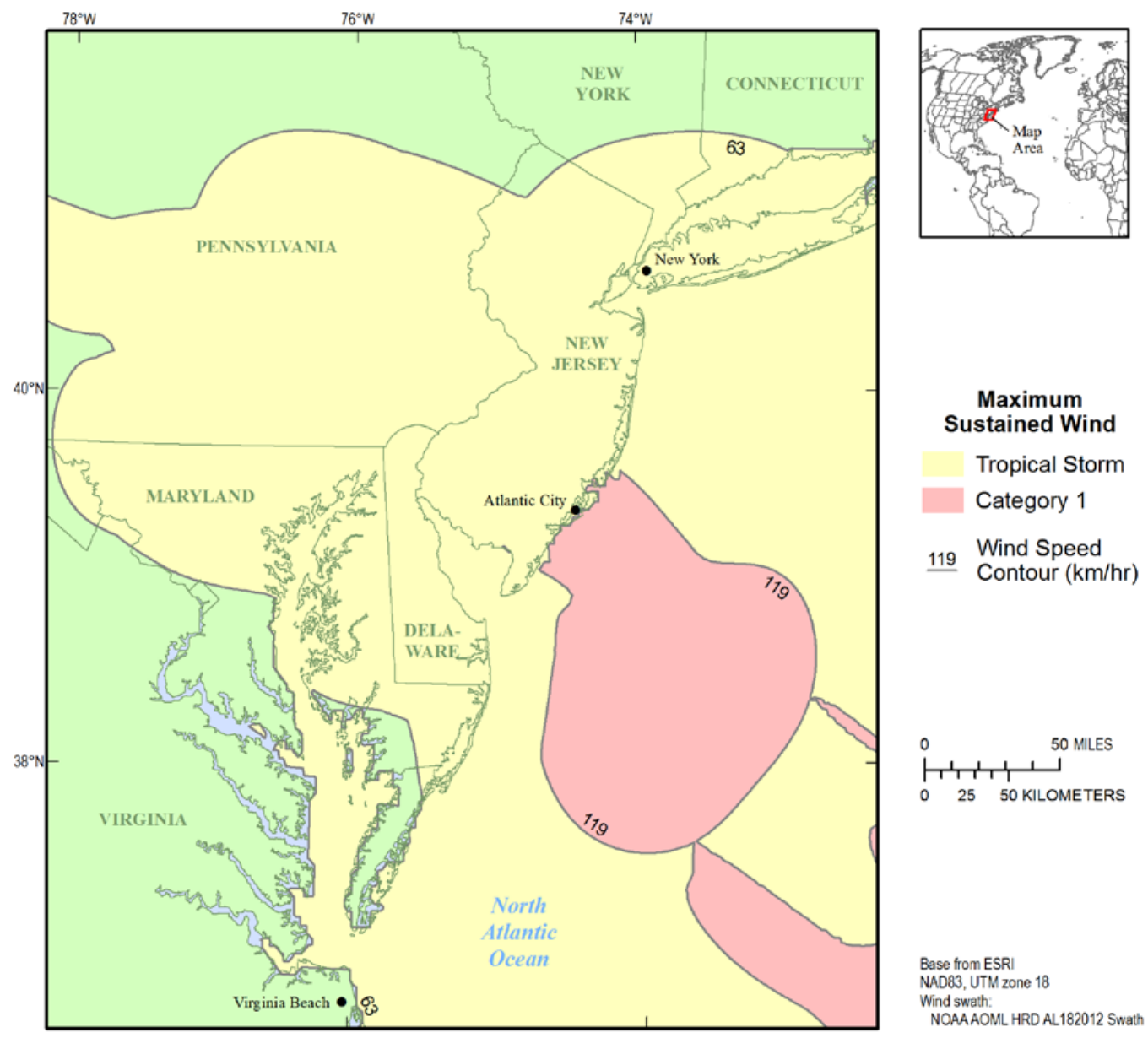

Base from ESRI

NAD83, UTM zone 18

Wind swath:

Figure 2. Maximum sustained wind speeds, in kilometers per hour $(\mathrm{km} / \mathrm{h})$, generated by Hurricane Sandy, as calculated by the NOAA Hurricane Research Division. The extent of hurricane-force wind, as defined by a category 1 wind speed of $119 \mathrm{~km} / \mathrm{h}$, is indicated by the light red contour.

\section{Wave Climate}

Several moored buoys (fig. 1) operated by the NOAA National Data Buoy Center (NDBC) measured heights and periods of waves generated by Hurricane Sandy. Approximately 23 hours prior to landfall, Hurricane Sandy passed within $170 \mathrm{~km}$ to the east of Buoy 41001, which is located $280 \mathrm{~km}$ east of Cape Hatteras, N.C. The maximum significant wave height $\left(\mathrm{H}_{\mathrm{s}}\right)$ recorded at this station was 10.1 meters (m) and the dominant wave period (T) was 12 seconds (s). Closer to the coast at Buoy 44065 (fig. 1) moored in $50 \mathrm{~m}$ of water at the entrance of the New York Harbor, approximately $28 \mathrm{~km}$ southeast of Breezy Point, N.Y., $\mathrm{H}_{\mathrm{s}}$ of $9.9 \mathrm{~m}$ (fig. 3) and T of $13 \mathrm{~s}$ were recorded at $0050 \mathrm{UTC}$ on October 30. A second NDBC buoy (44025) located $55 \mathrm{~km}$ south of Islip, N.Y., in $40 \mathrm{~m}$ of water, measured $\mathrm{H}_{\mathrm{s}}$ of $9.7 \mathrm{~m}$ (fig. 3) and $\mathrm{T}=14 \mathrm{~s}$ at $2350 \mathrm{UTC}$ on October 29. In an October 31 public information statement, the National Weather Service (NWS) Mt. Holly, N.J., office (2012) noted that waves generated by Sandy exceeded the previous records of $7.95 \mathrm{~m}$ recorded at Buoy 44065 during Hurricane Irene on August 28, 2011, and 9.30 m observed at Buoy 44025 during the December 1992 Nor'easter. 


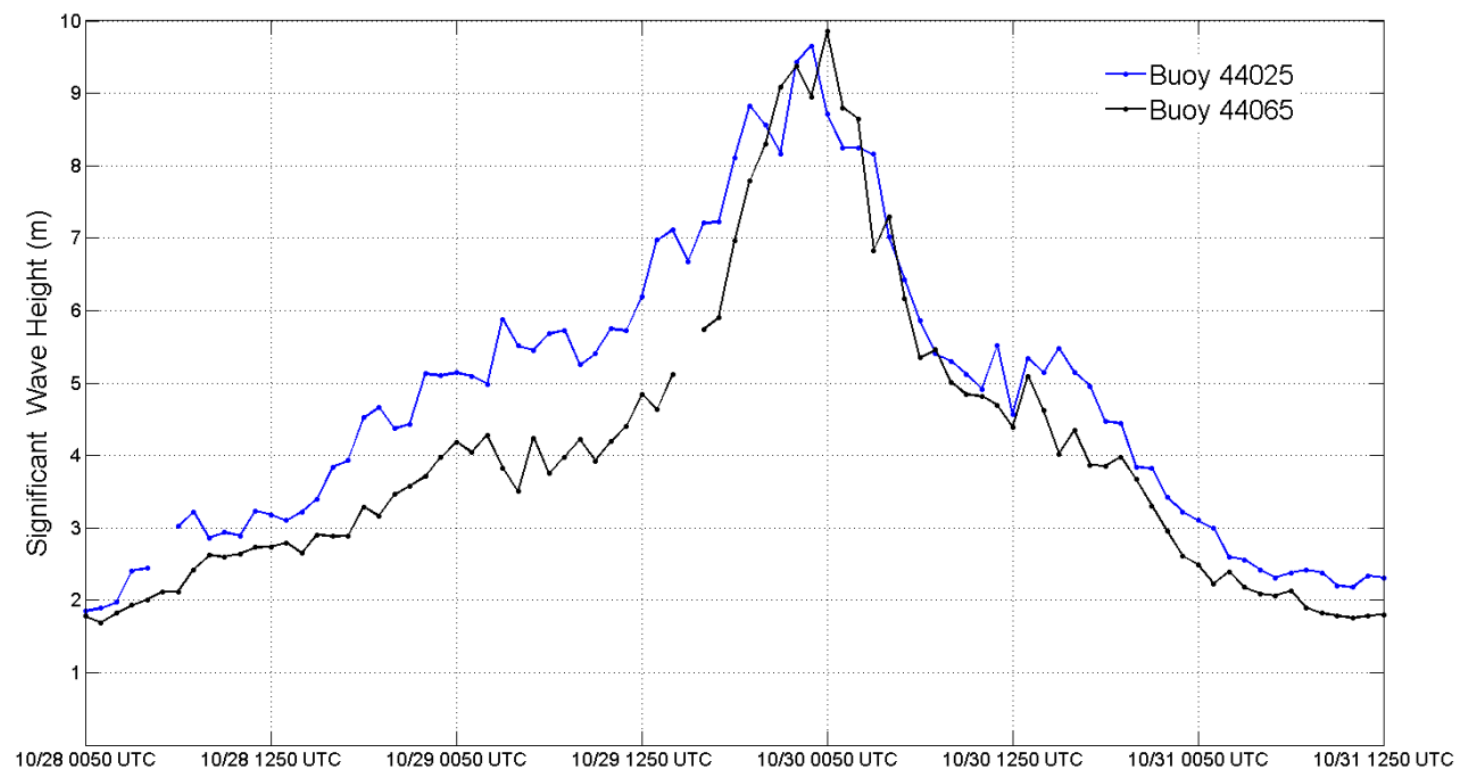

Figure 3. Significant wave height in meters $(m)$ during the passage of Hurricane Sandy, as measured nearshore by National Oceanic and Atmospheric Administration (NOAA), National Data Buoy Center (NDBC) buoys 44025 and 44065 .

\section{Storm Surge}

Measurements of storm surge are generally gathered from coastal tide gages and land-based storm sensors and high-water marks (McCallum and others, 2013). During Hurricane Sandy, many tide gages were operational and the data have been published by Blake and others (2013) and Fanelli and others (2013). Higher-than-normal water levels driven by Sandy's vast wind field affected the entire Eastern Seaboard. Maximum water levels, which include both storm surge and tide, exceeded normal tide levels by between $0.26 \mathrm{~m}$ and $0.68 \mathrm{~m}$ from the Florida Keys up through South Carolina. The U.S. Coast Guard Station at Hatteras Inlet, N.C., recorded water levels of $1.22 \mathrm{~m}$ above predicted tide level and a gage located at the mouth of Chesapeake Bay recorded a $1.19 \mathrm{~m}$ higher-than-predicted water level. Along the Maryland and Delaware Atlantic coasts, gages located at Oregon City Inlet, Md., and Lewes, Del., measured water levels of $1.14 \mathrm{~m}$ and $1.18 \mathrm{~m}$ above normal, respectively. The gage at Sandy Hook, N.J., registered a record water level of $2.61 \mathrm{~m}$ above normal before the sensor was destroyed. At The Battery, N.Y., gage, an observed peak water level of $2.87 \mathrm{~m}$ above predicted tide level also exceeded previous record water levels. Maximum surge and tide levels inland were determined from high-water marks taken from inside buildings and other locations shielded from wave impacts. A high-water mark recorded $1.71 \mathrm{~m}$ of water inland on Fire Island, N.Y., just east of the Fire Island Light. Oakwood, Staten Island, experienced $2.41 \mathrm{~m}$ of water inland, as confirmed by a high-water mark. At Sandy Hook, N.J., approximately $1.3 \mathrm{~km}$ northwest of the Sandy Hook Lighthouse, a highwater mark registered $2.71 \mathrm{~m}$ of water inland over normally dry land. 


\section{USGS Coastal-Change Observations}

The USGS National Assessment of Coastal Change Hazards Project responded to Hurricane Sandy with the following data-collection missions (fig. 4):

- Pre-storm airborne lidar topographic survey (completed October 26, 2012)

- Post-storm oblique aerial photography (completed November 6, 2012)

- Post-storm airborne lidar topographic survey (completed November 29, 2012)

These efforts are documented at http://coastal.er.usgs.gov/hurricanes/sandy/ and are described in more detail below.
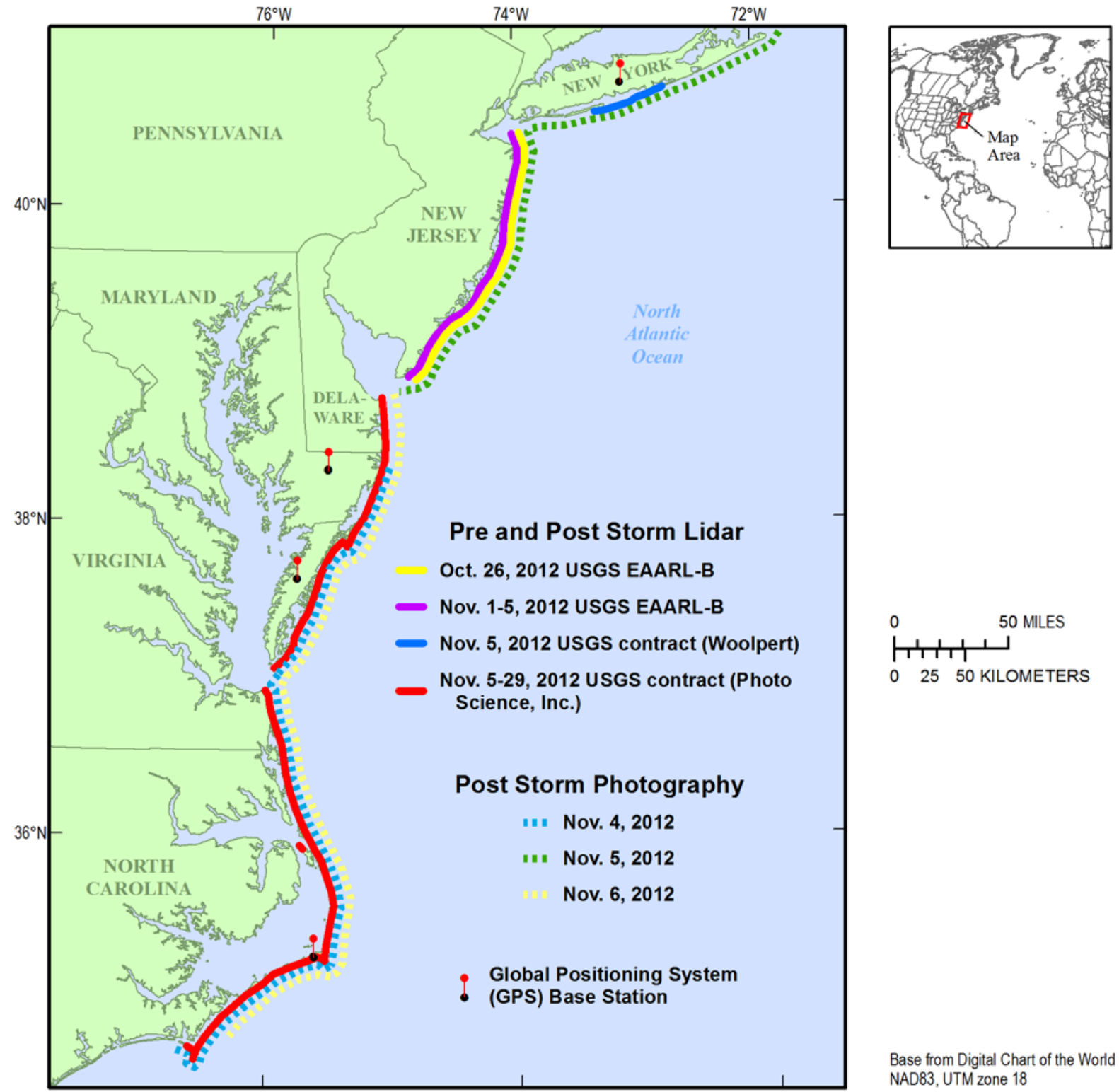

Base from Digital Chart of the World NAD83, UTM zone 18

Figure 4. Hurricane Sandy U.S. Geological Survey (USGS) and USGS-contracted post-storm oblique aerial photography, lidar coverage, and Global Positioning System (GPS) base station locations. 


\section{Oblique Aerial Photography}

Post-Hurricane Sandy oblique aerial photography of impacted regions was collected from November 4 through 6, 2012, beginning six days after landfall, from Cape Lookout, N.C., through Montauk Point, N.Y., a stretch of coastline approximately $1000 \mathrm{~km}$ long (fig. 4). Photography was captured with a Nikon D1X camera at a sample rate of one image every 2 to 3 seconds and recorded directly onto a computer hard drive using a compact digital imagery system, resulting in a total of 9206 images. Examples of both pre- and post-storm photographs obtained during these two flights are available online (http://coastal.er.usgs.gov/hurricanes/sandy/photo-comparisons/) and in the CoastalChange Analysis section. The complete library of pre- and post-Sandy photographs may be accessed at http://coastal.er.usgs.gov/hurricanes/sandy/post-storm-photos/obliquephotos.html/. Details of the photographs representing the pre-storm conditions are provided in table 1. In addition to supporting descriptions of the coastal changes that resulted from Hurricane Sandy, these data are available to emergency and coastal managers and others concerned with the storm's impact on the coast.

Table 1. Details of the pre-Hurricane Sandy photography collection.

\begin{tabular}{lll}
\hline Survey Date & Mission Type & Spatial Coverage \\
\hline August 30-31, 2011 & Post-Irene & North Carolina to Chesapeake Bay, Va. \\
May 21, 2009 & Baseline & Chesapeake Bay, Va., north through New York \\
\hline
\end{tabular}

\section{Lidar Topographic Surveys}

High-resolution lidar systems can map hundreds of kilometers of coast in a day with point densities exceeding one point per square meter. High point densities combined with reasonable horizontal and vertical accuracies allow for the creation of topographic and bathymetric digital-elevation models (DEM) that show details of the coastal environment (Stockdon and others, 2013). Vertical accuracy of the lidar survey data is expected to be on the order of 10-20 centimeters $(\mathrm{cm})$ (Sallenger and others, 2003), whereas the horizontal-position accuracy is on the order of $1 \mathrm{~m}$ (Nayegandhi and others, 2009).

Because of the enormous size of the area affected by Hurricane Sandy, post-storm lidar surveys described here were obtained using several survey approaches including USGS Experimental Advanced Airborne Research Lidar (EAARL-B), a new generation of the EAARL system (C.W. Wright and R. Troche, oral commun., 2013), which conducted both pre- and post-storm surveys, and commercial contract surveys using a variety of sensors and platforms (fig. 4). Also, because of the large spatial extent of the post-storm surveys, several different survey dates were required to define the pre-storm topography. The survey dates and spatial coverage for each pre-storm survey are detailed in table 2. Examples of pre- and post-storm comparisons of lidar elevation are available online (http://coastal.er.usgs.gov/hurricanes/sandy/lidar/) and in the Coastal-Change Analysis section. Details of the individual post-Hurricane Sandy lidar surveys are described in the following subsections. 
Table 2. Details of the pre-Hurricane Sandy lidar data used for coastal-change analysis.

\begin{tabular}{lll}
\hline Survey Date & Instrument & Spatial Coverage \\
\hline May 4- June 16, 2010 & CHARTS* $^{*}$ & Beaufort, N.C., to Cape Lookout, N.C. \\
August 9-24, 2009 & CHARTS & Cape Lookout, N.C., to the North Carolina/Virginia border \\
November 27-December 4, 2009 & EAARL & Virginia \\
September 11-25, 2010 & CHARTS & Maryland through Delaware \\
October 26, 2012 & EAARL & New Jersey \\
May 7, 2012 & Contractor & Fire Island, N.Y. \\
August 19-27, 2010 & CHARTS & New York except Fire Island, N.Y. \\
\hline
\end{tabular}

* Compact Hydrographic Airborne Rapid Total Survey (CHARTS) is the U.S. Army Corps of Engineers (USACE) lidar survey system (Wozencraft and Millar, 2005).

\section{Cape Lookout, North Carolina, through Delaware}

\section{Lidar Flight Information}

A contract airborne lidar survey of post-storm coastal topography from Cape Lookout, N.C., northward through Virginia, Maryland, and Delaware, began on November 5, 2012, seven days after landfall, and was completed on November 29, 2012. The project required a total of 12 flight days within this timeframe. Two Cessna 206 aircraft, one mounted with a Leica LiDAR Sensor and the other equipped with an Optech Gemini LiDAR Sensor, surveyed approximately $570 \mathrm{~km}$ of coastline in a total of seventeen aircraft lifts. The three-dimensional point-cloud data in .las format, digital-elevation maps (DEMs) generated from this dataset, and metadata files associated with this survey have been published in a U.S. Geological Survey Data Series report (Stockdon and others, 2013).

\section{Lidar Control GPS Base Stations}

Three GPS base stations were used during all phases of flight operations. Station position was confirmed with the National Geodetic Survey Online Positioning User Service and multiple surveys. Instrumentation details and precise locations, including ellipsoidal height, for each station are listed in table 3 .

Table 3. Details of autonomous GPS control stations used during the November $5-29,2012$, contract lidar mission.

\begin{tabular}{lllll}
\hline Station ID & North Latitude & West Longitude & $\begin{array}{c}\text { Ellipsoidal Height } \\
\text { (WGS84), in meters }\end{array}$ & Description \\
\hline MFV & $37^{\circ} 38^{\prime} 32.94549^{\prime \prime}$ & $75^{\circ} 45^{\prime} 42.89703^{\prime \prime}$ & -23.252 & Contractor/ Accomack County Airport, Virginia \\
KHSE & $35^{\circ} 13^{\prime} 59.01384^{\prime \prime}$ & $75^{\circ} 37^{\prime} 05.17798^{\prime \prime}$ & -35.363 & Contractor/ Billy Mitchell Airport, North Carolina \\
KSBY1 & $38^{\circ} 20^{\prime} 18.45512^{\prime \prime}$ & $75^{\circ} 31^{\prime} 05.51300^{\prime \prime}$ & -23.101 & $\begin{array}{c}\text { Contractor/ Salisbury-Ocean City Wicomico } \\
\text { Regional Airport, Maryland }\end{array}$ \\
\hline
\end{tabular}




\section{Lidar Quality}

Verification of the vertical accuracy of the lidar data was accomplished by comparison of a GPS ground survey of elevations at 27 control points throughout the mission area (fig. 4) to airborne lidar surveys of the control locations. Lidar-derived elevations differed from known elevations for all control points by an average of $-0.009 \mathrm{~m}$ with a RMSE (root-mean-square error; the root of the average of the squared differences between known and lidar-measured elevations) of $0.101 \mathrm{~m}$. This is within acceptable vertical-error tolerance.

\section{New Jersey}

\section{Lidar Flight Information}

An airborne lidar survey of pre-storm topography of the New Jersey coastline was carried out on October 26, 2012, three days prior to landfall, using the EAARL-B system mounted on a twin-engine Cessna 310 aircraft. This survey covered $210 \mathrm{~km}$ of the New Jersey coast from Cape May Point north to Sandy Hook (fig. 4).

A second survey of the New Jersey coast was conducted beginning November 1, 2012, three days after storm landfall near Brigantine, N.J., using the same aircraft and USGS EAARL-B system. The post-storm survey was completed on November 5, 2012.

Lidar elevation data from both surveys were processed with software written specifically for the lidar instrument (Bonisteel and others, 2009). Coastal-change parameters computed from EAARL-B pre- and post-storm surveys and presented here are considered preliminary. They are based on provisional data that may be updated as the survey accuracy improves in future processing steps, such as application of the precise ephemeris for GPS satellites, offset checks using ground-control surveys, checks for laser calibration and mounting errors, and full application of data quality control, assurance and editing procedures. EAARL-B pre- and post-storm data presented in this report have undergone automated filtering and preliminary manual editing has been performed.

The three-dimensional point-cloud data collected during the USGS EAARL-B pre- and poststorm surveys, digital-elevation maps (DEMs) generated from this data, and associated metadata files will be published in a U.S. Geological Survey Data Series (C.W. Wright, oral commun., 2014)

\section{Lidar Control GPS Base Stations}

The USGS pre- and post-landfall surveys of the New Jersey coastal region utilized the publicly available data from the NOAA Continuously Operating Reference Station (CORS) network of ground base stations. Additionally, a GPS base station located at the Salisbury-Ocean City Wicomico Regional Airport was used during airborne lidar acquisition (see table 4 for details). 
Table 4. Details of the Global Positioning System (GPS) control station used during the October 26 and November 1-5, 2012, U.S. Geological Survey (USGS) lidar missions.

\begin{tabular}{lllll}
\hline Station ID & North Latitude & West Longitude & $\begin{array}{l}\text { Ellipsoidal Height } \\
\text { (WGS84), in meters }\end{array}$ & Description \\
\hline KSBY2 & $38^{\circ} 20^{\prime} 7.6122$ & $-75^{\circ} 31^{\prime} 10.2786^{\prime \prime}$ & -17.491 & $\begin{array}{c}\text { USGS/ Salisbury-Ocean City Wicomico } \\
\text { Regional Airport, Maryland }\end{array}$ \\
\hline
\end{tabular}

\section{Lidar Quality}

The Richard Stockton College of New Jersey Coastal Research Center (CRC) conducted a ground-based elevation survey of the New Jersey coastline pre- and post-landfall (D. Barone, email commun., 2012). Only ground-based beach transect elevations acquired concurrently with airborne lidar collection can be used to ground truth lidar data, restricting the comparison to post-Sandy data collected on November 1, 2012. Of the 105 New Jersey Beach Profile Network (NJBPN) transects, the CRC collected elevation data along seven (Profile Location IDs: 234, 135, and 137-141;

http://www.stockton.edu/crc/) located on Long Beach Island, N.J., from Holgate north through Ship Bottom (fig. 5).
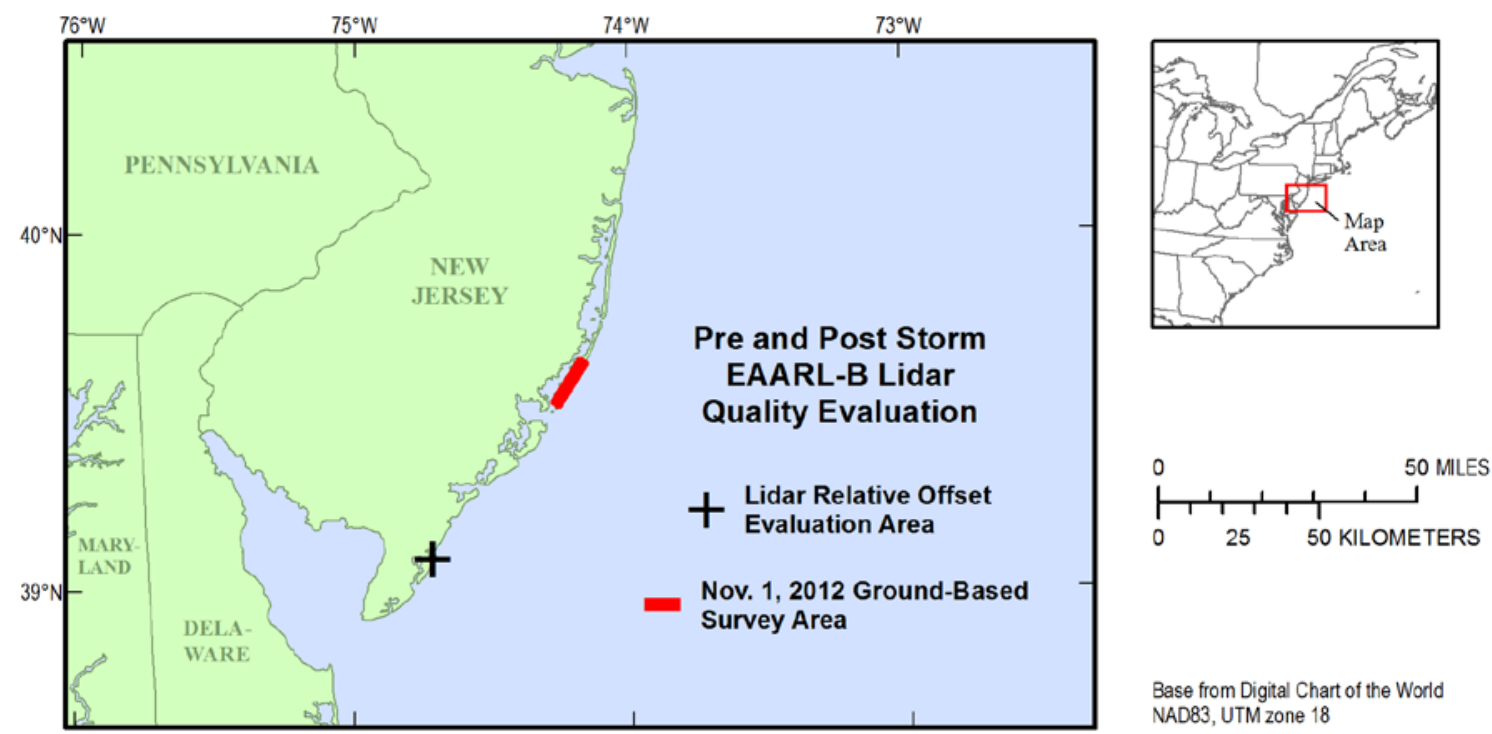

Figure 5. Hurricane Sandy lidar relative offset evaluation location for U.S. Geological Survey (USGS) pre- and post-storm Experimental Advanced Airborne Research Lidar (EAARL-B) surveys and post-storm ground-based survey area.

Comparison of ground- and aerial-based elevations was accomplished by finding the nearest neighboring member of the lidar first-return point cloud, restricted to within a $1 \mathrm{~m}$ radius (within typical horizontal error for airborne lidar-based data), to each beach elevation survey location. Elevation comparison was limited to survey points located seaward of the dune toe to eliminate vegetation and buildings included in the first-return lidar data, resulting in an average vertical error of $-0.254 \mathrm{~m}$ and a RMSE of $0.263 \mathrm{~m}$ (fig. 6). Total RMSE for all ground-based elevations surveyed on November 1, 2012, including locations landward of the dune toe, was $0.820 \mathrm{~m}(\mathrm{n}=90)$. 


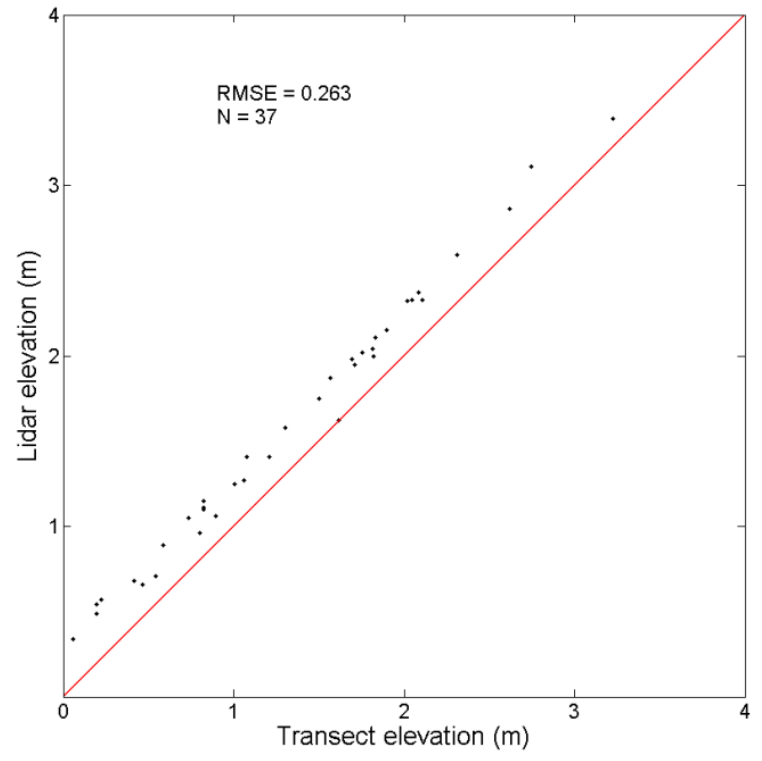

Figure 6. November 1, 2012, Experimental Advanced Airborne Research Lidar (EAARL-B) first-return lidar elevations versus New Jersey Beach Profile Network (NJBPN) transect elevations, in meters (m), measured November 1, 2012.

Since no ground surveys were conducted concurrent with the pre-Hurricane Sandy USGS EAARL-B lidar survey, the relative offsets between gridded lidar point-cloud data from the two EAARL-B surveys and from an August 2010 U.S. Army Corps of Engineers (USACE) contract survey of the same region were determined. A large, paved area in Avalon, N.J., south of the landfall location, was chosen as a test site (fig. 5). Because only first-return lidar data were available from the EAARL-B surveys, direct comparison of the August 2010 last-return lidar elevations to first-return lidar points from both EAARL-B surveys required a test site with a fixed, flat region that was free of vegetation. Examination of oblique imagery taken of the chosen test location pre-storm alongside photos acquired during the USGS post-landfall aerial photography survey insured that the area remained free of sand or debris.

First-return lidar elevations from both the October 2012 and November 2012 EAARL-B surveys and last-return points from the August 2010 survey were interpolated to a series of regular 2 m- by 2 mgrid domains within the test region. The interpolation method applied a smoothing filter that removed short-scale variability and determined the degree to which residual noise had been removed (Plant and others, 2002). Elevations and grid points that received too few observations were removed to reduce system noise. The grid cells were used to determine a relative offset of $-0.03 \mathrm{~m}( \pm 0.05 \mathrm{~m})$ between the October 2012 USGS EAARL-B survey and the August 2010 USACE Compact Hydrographic Airborne Rapid Total Survey (CHARTS) and a relative offset of $+0.04 \mathrm{~m}( \pm 0.05 \mathrm{~m})$ between the November 2012 EAARL-B survey and the August 2010 survey (fig. 7). These values are well within the expected vertical error of the lidar data and are not statistically significant. 


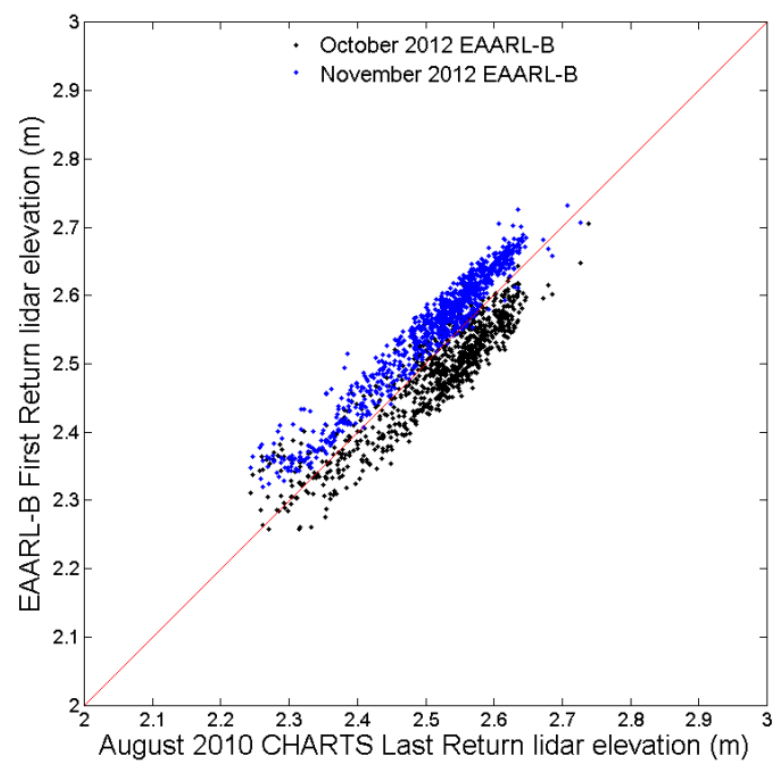

Figure 7. August 2010 Compact Hydrographic Airborne Rapid Total Survey (CHARTS) last-return lidar elevations versus October 2012 Experimental Advanced Airborne Research Lidar (EAARL-B) (black) and November 2012 EAARL-B (blue) first-return lidar elevations; in meters (m).

\section{Fire Island, New York}

\section{Lidar Flight Information}

Post-storm topographical data from Fire Island, N.Y., were acquired during a USGS contracted airborne lidar survey completed in one mission on November 5, 2012. Lidar data from approximately 50 $\mathrm{km}$ of shoreline (fig. 4) were collected with an Optech Gemini LiDAR Sensor mounted on a Cessna 310 aircraft.

\section{Lidar Control GPS Base Stations}

A GPS base station was established at Long Island MacArthur Airport in support of the airborne lidar acquisition mission (see table 5 for details).

Table 5. Details of the Global Positioning System (GPS) control station used during the November 5, 2012, contract lidar mission of Fire Island, New York.

\begin{tabular}{lllll}
\hline Station ID & North Latitude & West Longitude & $\begin{array}{l}\text { Ellipsoidal Height } \\
\text { (WGS84), in meters }\end{array}$ & Description \\
\hline KISP & $40^{\circ} 47^{\prime} 50.55891^{\prime \prime}$ & $073^{\circ} 05^{\prime} 58.93690^{\prime \prime}$ & -4.571 & Contractor/ Long Island MacArthur Airport, New York \\
\hline
\end{tabular}




\section{Lidar Quality}

The USGS conducted a GPS ground survey of 5 control points within the mission area (fig. 4). A comparison of airborne laser-derived elevations to known elevations at these control points resulted in a vertical-error magnitude of $0.063 \mathrm{~m}$ on average and a computed RMSE of $0.075 \mathrm{~m}$.

\section{Coastal-Change Analysis}

Hurricane Sandy affected the coastlines over a broad swath of the northeast and Mid-Atlantic, including New York, New Jersey, Delaware, Maryland, Virginia, and North Carolina. Breaching, overwash, and erosion took place on many barrier islands, including some that are heavily populated and developed. Comparisons of pre- and post-storm photography were used to identify examples of coastal changes that span the range of responses to the hurricane conditions (fig. 8). The pre-storm photography was obtained during the times described in table 1. 

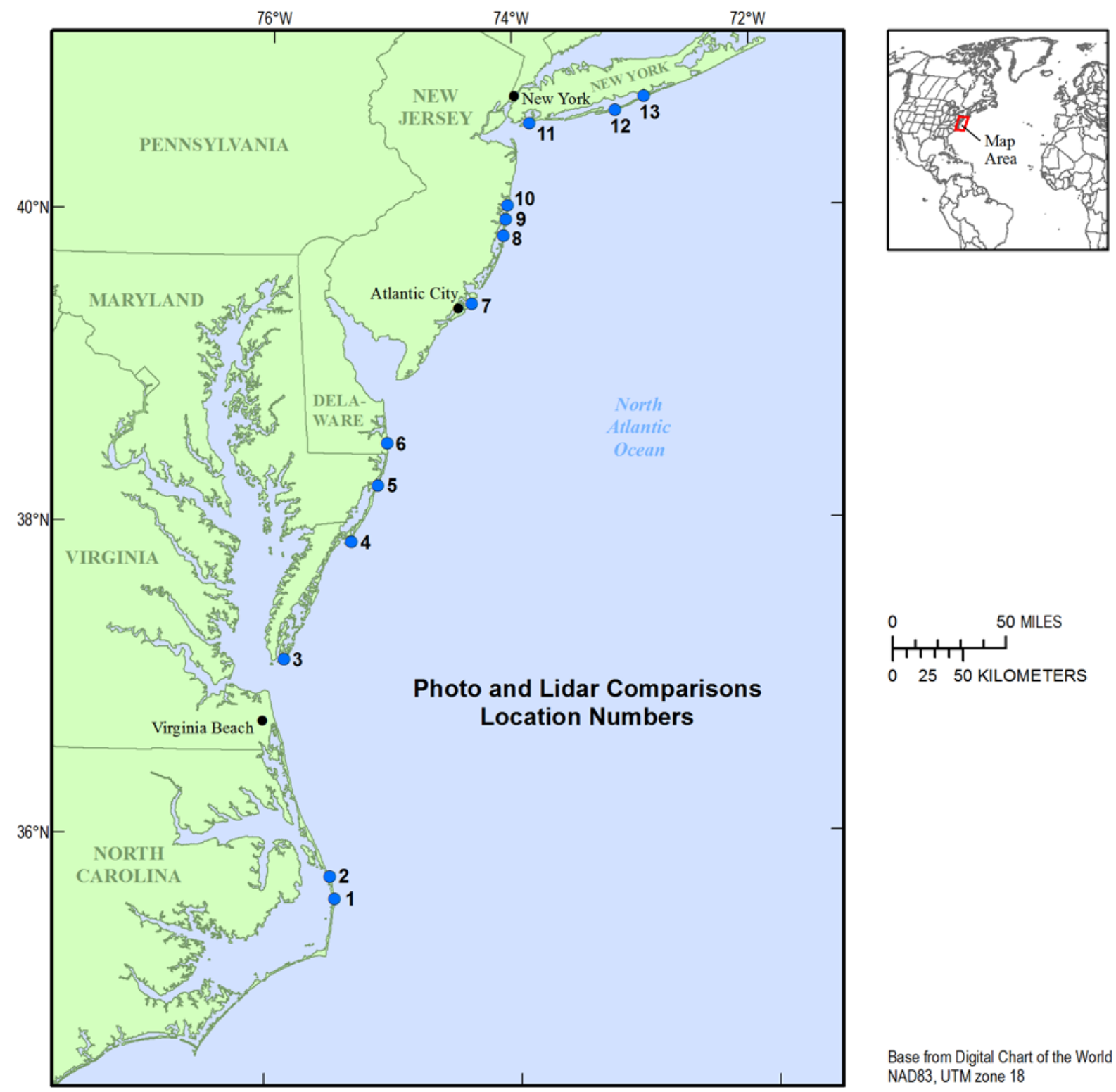

Base from Digital Chart of the World NAD83, UTM zone 18

Figure 8. Map of location index for photo pairs and pre- and post-Hurricane Sandy lidar comparisons.

Pre- and post-Hurricane Sandy lidar elevation surveys were compared to quantify the spatial extent and magnitude of these coastal changes. As with the pre-storm photographs, pre-storm lidar surveys were also obtained from a variety of sources (table 2). After collection, the lidar data are processed to remove spurious data points and to separate points into first- and last-return lidar products which are selected from the first and last backscatter to return to the sensor from the laser pulse. First returns can be used to estimate canopy height in vegetated areas or rooftop height in developed areas, while last returns can be used to estimate elevation of the bare-Earth surface under vegetation (Flood, 2001). For these analyses, lidar last-return data were gridded for identifying shorelines and dune height. The analysis included spatial filtering with a Hanning window and optimal interpolation to a gridded domain that was rotated parallel to the shoreline and had a resolution of $10 \mathrm{~m}$ in the alongshore direction and $2.5 \mathrm{~m}$ in the cross-shore direction (Plant and others, 2002). Interpolation to common grids allows visualization of the pre- and post-storm elevations and topographic change. 
Additional quantitative analyses include estimation of changes in dune height, shoreline position, and subaerial sediment volume. The interpolated lidar elevations were used to compute changes in elevation and position of the frontal sand dune or berm system, shoreline position, and beach volume. The cross-shore location of the peak elevation of the seaward-most sand dune is extracted from gridded pre-storm elevation (Stockdon and others, 2009). The difference between post- and preHurricane Sandy elevation at this location defines storm-induced dune or berm-elevation change in meters. To calculate the shoreline position, the cross-shore position of the mean-high-water line (defined from tidal records; table 6) was extracted at $10 \mathrm{~m}$ intervals in the alongshore direction from gridded elevation data (Stockdon and others, 2002; Weber and others, 2005). Typical errors in shoreline position are on the order of 1 to $2 \mathrm{~m}$ (Stockdon and others, 2002); however, uncertainty will vary due to data noise and beach slope. Shoreline change (in meters) was calculated as the difference between the pre- and post-storm horizontal shoreline position. The subaerial beach volume change is calculated between the locations of pre-storm dune base and shoreline at $10 \mathrm{~m}$ intervals in the alongshore direction by differencing the pre- and post-storm elevation grids and integrating the differenced values in the cross-shore direction, yielding the volume change (in cubic meters) per meter length of coastline. This eliminates complications from structures and vegetation, which generally are located landward of the dune base. The results of the coastal-change analysis are presented in separate subsections including the five coastal states within our storm response region.

Because the storm provides the forcing for the majority of observed coastal changes, we present dune, shoreline and beach-volume change relative to the location of landfall. The magnitudes of erosion typically scale with distance from landfall $(D F L)$, where negative values represent distance along the shoreline to the left of landfall and positive values indicate distance, moving along the coast, to the right of landfall.

Table 6. Details of the mean-high-water line used for coastal-change analysis, in meters (m).

\begin{tabular}{ll}
\hline Location of Mean-High-Water Line Above Mean Sea Level & Spatial Coverage \\
\hline $0.26 \mathrm{~m}$ & Cape Lookout, N.C., to the mouth of Chesapeake Bay \\
$0.34 \mathrm{~m}$ & Virginia north of Chesapeake Bay through Cape Henlopen, Del. \\
$0.43 \mathrm{~m}$ & New Jersey \\
$0.46 \mathrm{~m}$ & New York \\
\hline
\end{tabular}

\section{North Carolina}

Extreme dune-elevation changes of $4 \mathrm{~m}$ or more were observed along much of the Outer Banks of North Carolina. From the Cape Hatteras Lighthouse $(D F L=-472 \mathrm{~km})$ north to Oregon Inlet $(D F L=-$ $420 \mathrm{~km}$ ), nearly 14 percent of the dunes experienced $2 \mathrm{~m}$ or more in dune-height erosion (fig. 9A). In Rodanthe, Hatteras Island, N.C., storm surge and waves eroded the dunes and the beach, depositing sand inland and shifting the shoreline landward (figs. 9B, 10 and 11). Prior to the storm, several houses sat on top of, or just seaward of, the dunes or highest elevations on this part of Hatteras Island. Dune erosion and landward shoreline migration left many of these houses vulnerable to future storms. Storm surge and waves produced overwash that deposited sand on coastal roads. Further north, waves eroded the face of dunes in Corolla, N.C. (fig. 9A). Approximately $475 \mathrm{~km}$ to the left (south) of landfall, the 
southward migration of the tip of Cape Hatteras can be seen in the rapid shift from shoreline accretion to retreat moving from south to north (fig. $9 B$ ), a pattern mirrored by a gain in beach volume ( $D F L=-475$ km, fig. 9C). 
Dune elevation change
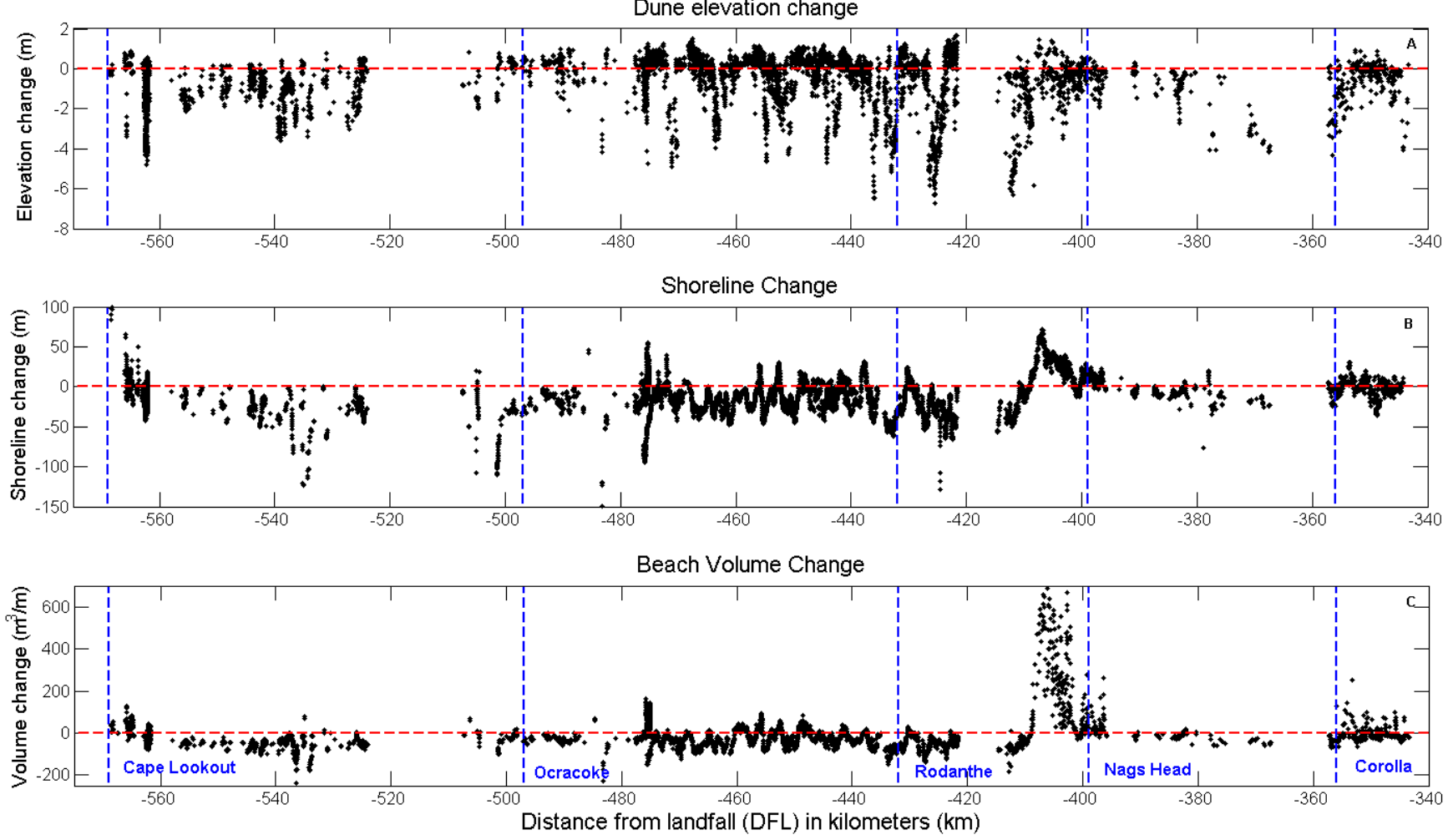

Figure 9. Hurricane Sandy $(A)$ dune-elevation change, $(B)$ shoreline change, and $(C)$ beach-volume change between August 2009 and November 2012 for the North Carolina barrier-island coast. Vertical dashed lines indicate the center of Cape Lookout, Ocracoke Island, and the towns of Rodanthe, Nags Head, and Corolla, respectively. Measurements are in meters $(\mathrm{m})$, cubic meters per meter ( $\left.\mathrm{m}^{3} / \mathrm{m}\right)$, and kilometers $(\mathrm{km})$. 

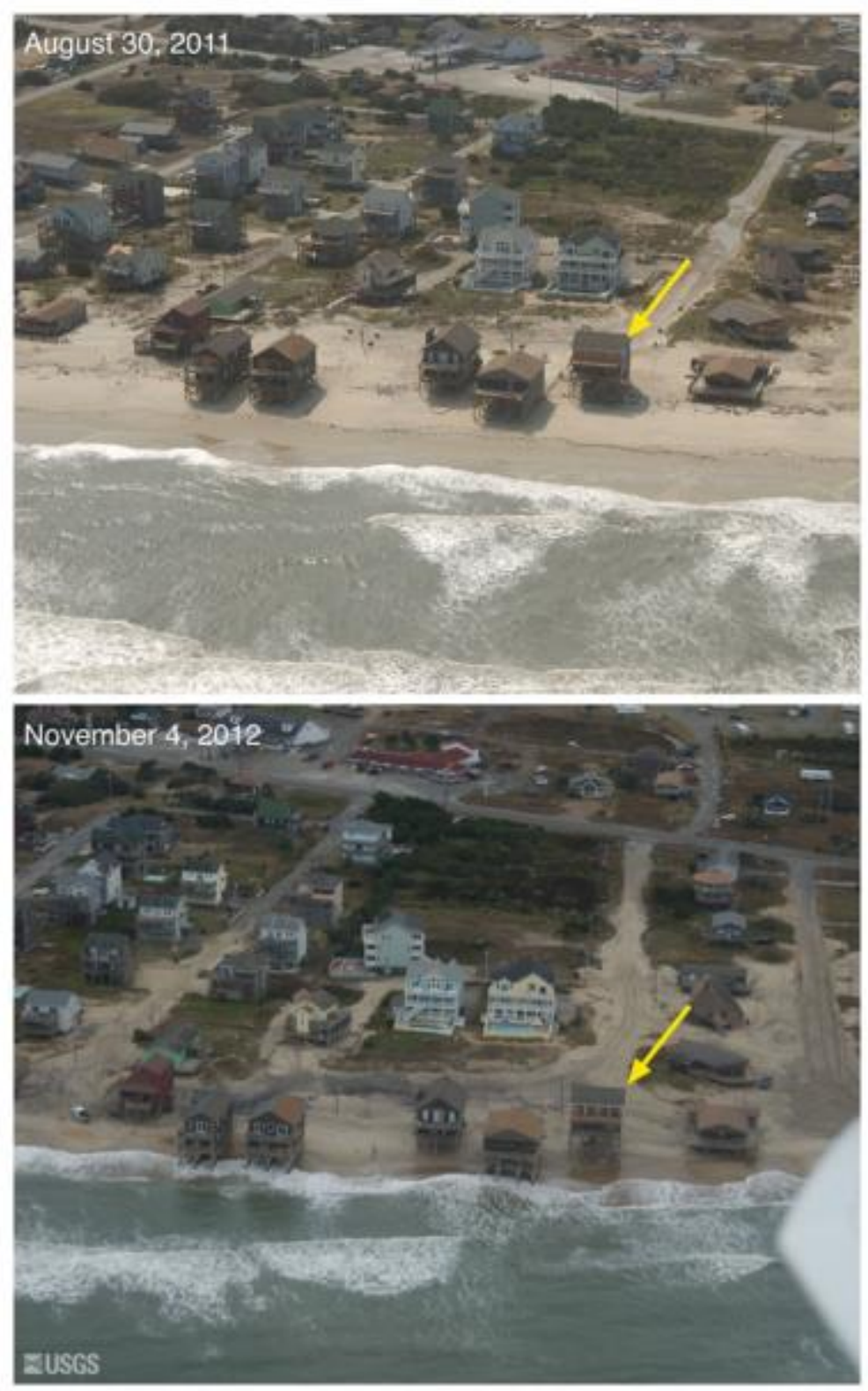

Figure 10. North Carolina location 1 (distance from landfall (DFL) -434 kilometers): oblique aerial photographs of Rodanthe, North Carolina. View looking west across the North Carolina shore. Beach erosion moved the shoreline landward to reach houses built on the beach. The yellow arrow in each image points to the same feature. 

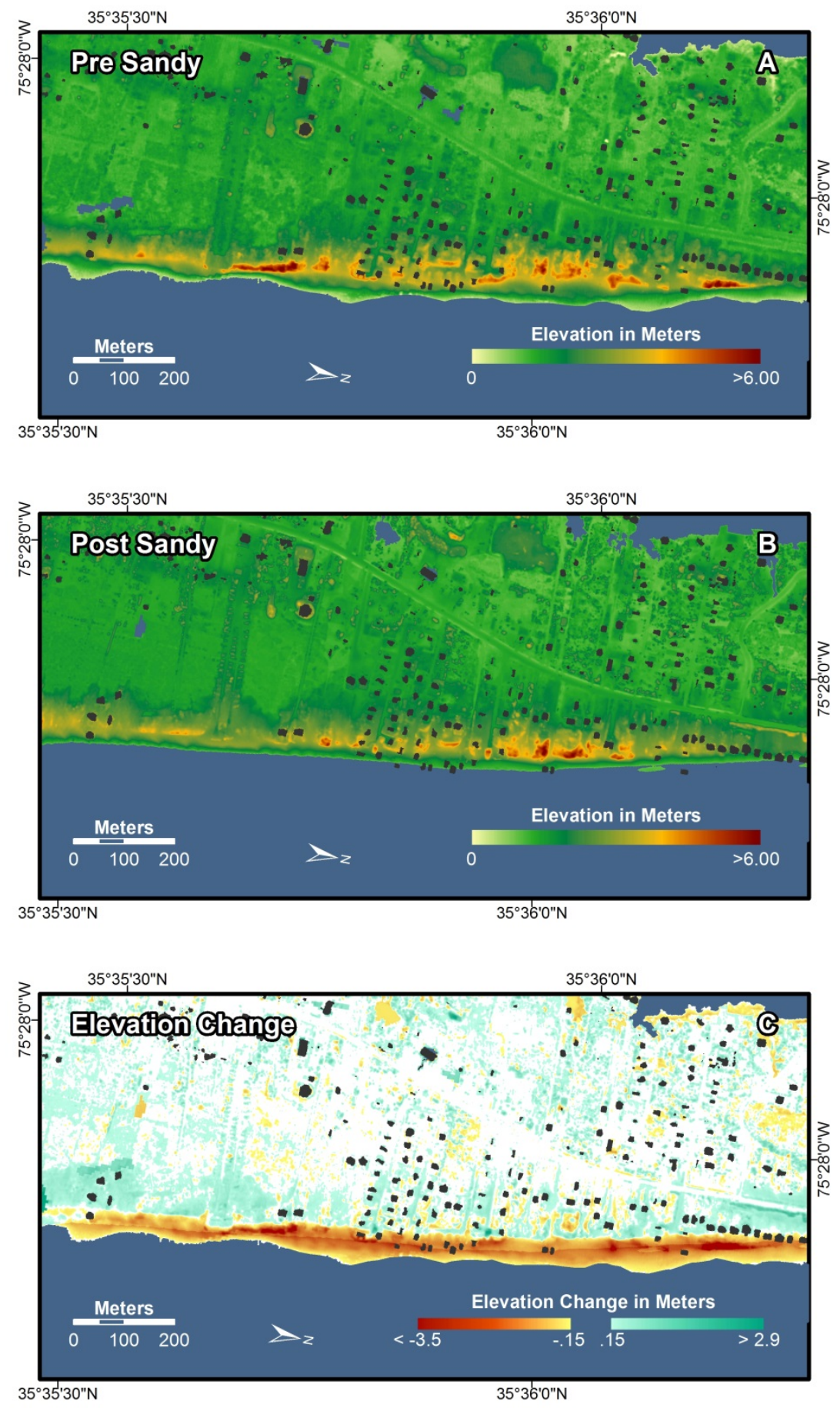

Figure 11. Three-dimensional lidar topography, before (November 2009; A) and after (November 2012; B) Hurricane Sandy; and elevation change $(C)$ at location 1 (fig. 8), Rodanthe, Kinnakeet Township, North Carolina. The relatively high elevation of the houses has been identified and marked with black shading on the maps. 
Estimates of coastal change over this time span incorporate the impacts of both Nor'Ida (November 2009) and Hurricane Irene (August 2011), in addition to Hurricane Sandy; however, it is likely there was some natural recovery of the beach system between these smaller storms and Sandy. Identification of damage to infrastructure and dune and beach erosion specific to Sandy is possible by comparing photographs taken post-Hurricane Irene to those acquired post-Sandy. For example, the sharp shoreline retreat $(D F L \sim-425 \mathrm{~km}$ ) visible north of Rodanthe and south of Oregon Inlet (centered around $D F L \sim-418 \mathrm{~km}$ ) pinpoints the location of New Inlet where surge and waves driven by Hurricane Irene cut through the barrier island just south of Pea Island National Wildlife Refuge, destroying a portion of Hwy 12. Prior to Sandy, the dunes here varied in height and width. During Hurricane Sandy, the lower and narrower dunes were overwashed by waves and storm surge that carried sand from the beach and dunes and deposited it on the road and marsh in overwash fans. Significant new damage to the stretch of Highway 12 running through the Pea Island National Wildlife Refuge was caused by Sandy. Much of the roadway was buried under large overwash deposits (figs. 12 and 13), and the pavement buckled south of New Inlet (North Carolina Department of Transportation, 2012).

The anomalous increase in beach width and volume appearing south of Nags Head (fig. 9B, C) is the result of a beach renourishment project undertaken in May through October of 2011, after the prestorm lidar survey was flown (Kana and Kaczkowski, 2011). 

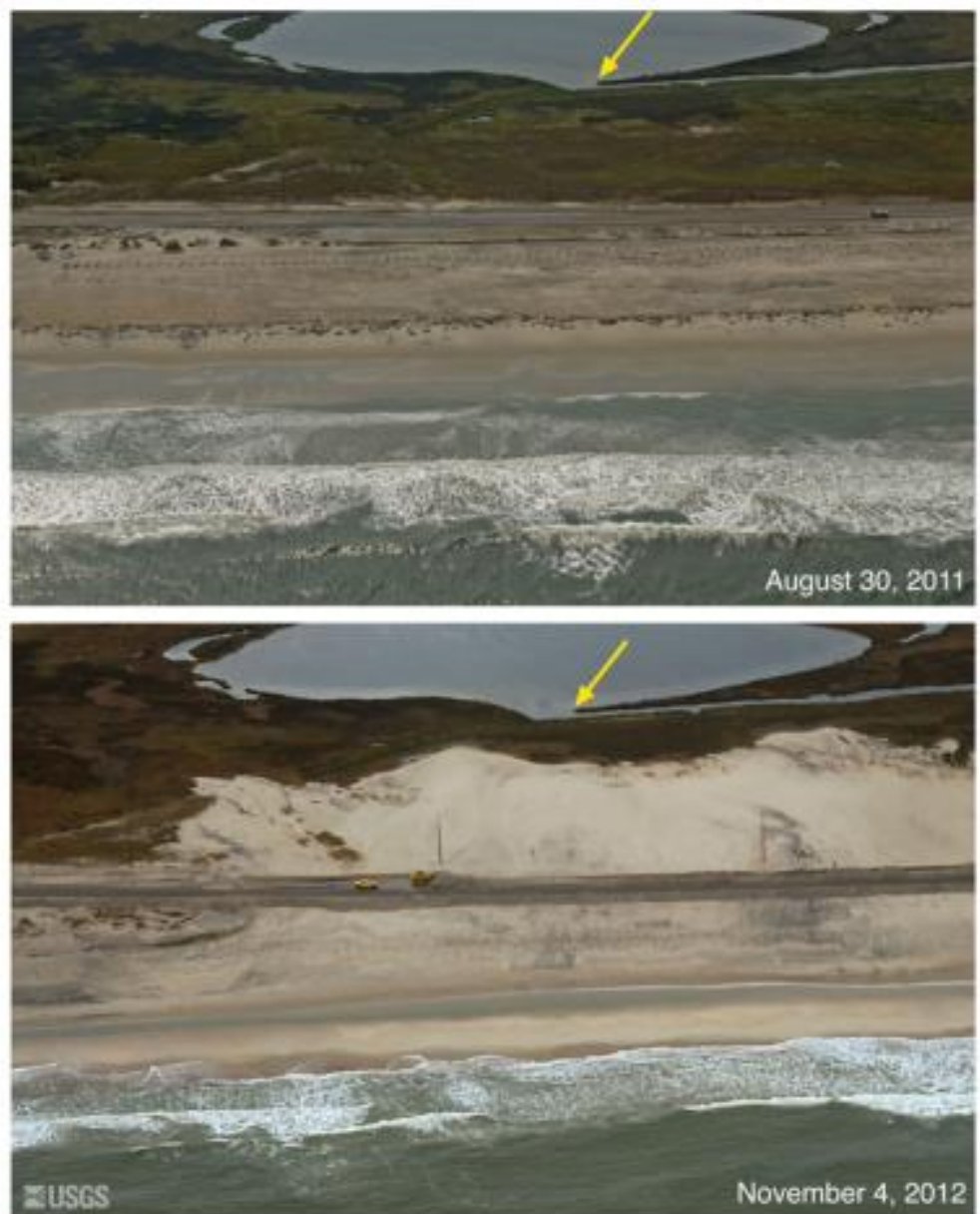

Figure 12. North Carolina location 2 (distance from landfall (DFL) -422 kilometers): oblique aerial photographs of Pea Island National Wildlife Refuge, Kinnakeet Township, North Carolina. View looking west across the North Carolina shore. Extensive overwash is evident here. The yellow arrow in each image points to the same feature. 

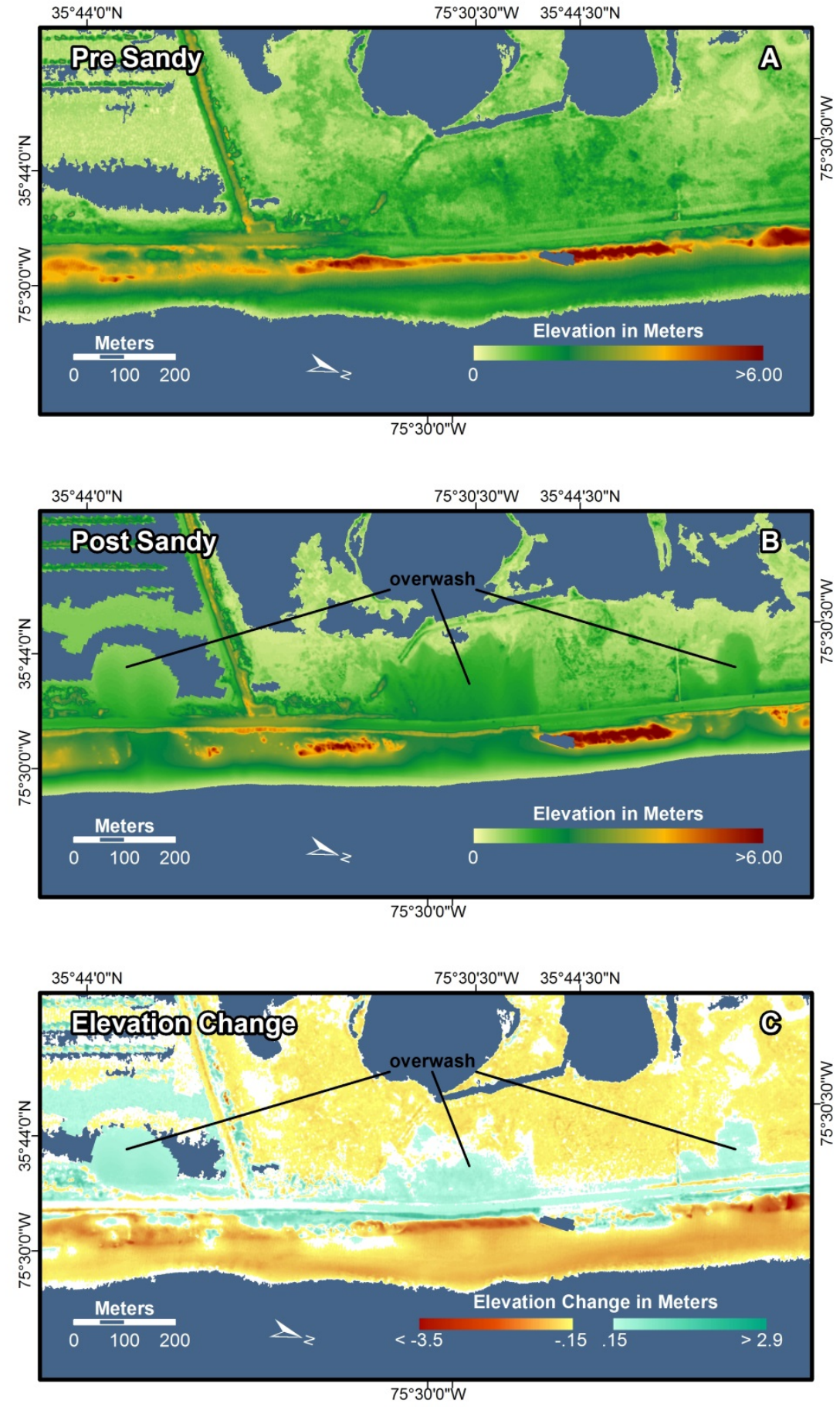

Figure 13. Three-dimensional lidar topography, before (November 2009; $A$ ) and after (November 2012; B) Hurricane Sandy; and elevation change $(C)$ of location 2 (fig. 8), Pea Island National Wildlife Refuge, Kinnakeet Township, North Carolina. 


\section{Virginia}

Along the undeveloped Virginia coastline south of Virginia Beach, relatively little volume change occurred and high dunes averaging $6.6 \mathrm{~m}$ in elevation protected against overwash and inundation (fig. 14C). However, waves and elevated water level contributed to dune erosion and scarping (fig. 14A) reducing dune height by a mean of $1.4 \mathrm{~m}$ from the North Carolina/Virginia border $(D F L=-344 \mathrm{~km})$ northward to around $D F L=-330 \mathrm{~km}$. For the approximate $5 \mathrm{~km}$ length of the coast centered on Virginia Beach, the beach is backed by a boardwalk, which represents the peak dune height in this location. The boardwalk remained intact through Hurricane Sandy, therefore dune height is unchanged and dune erosion here is zero. However, volume loss and narrowing of the beach occurred in front of the boardwalk. 

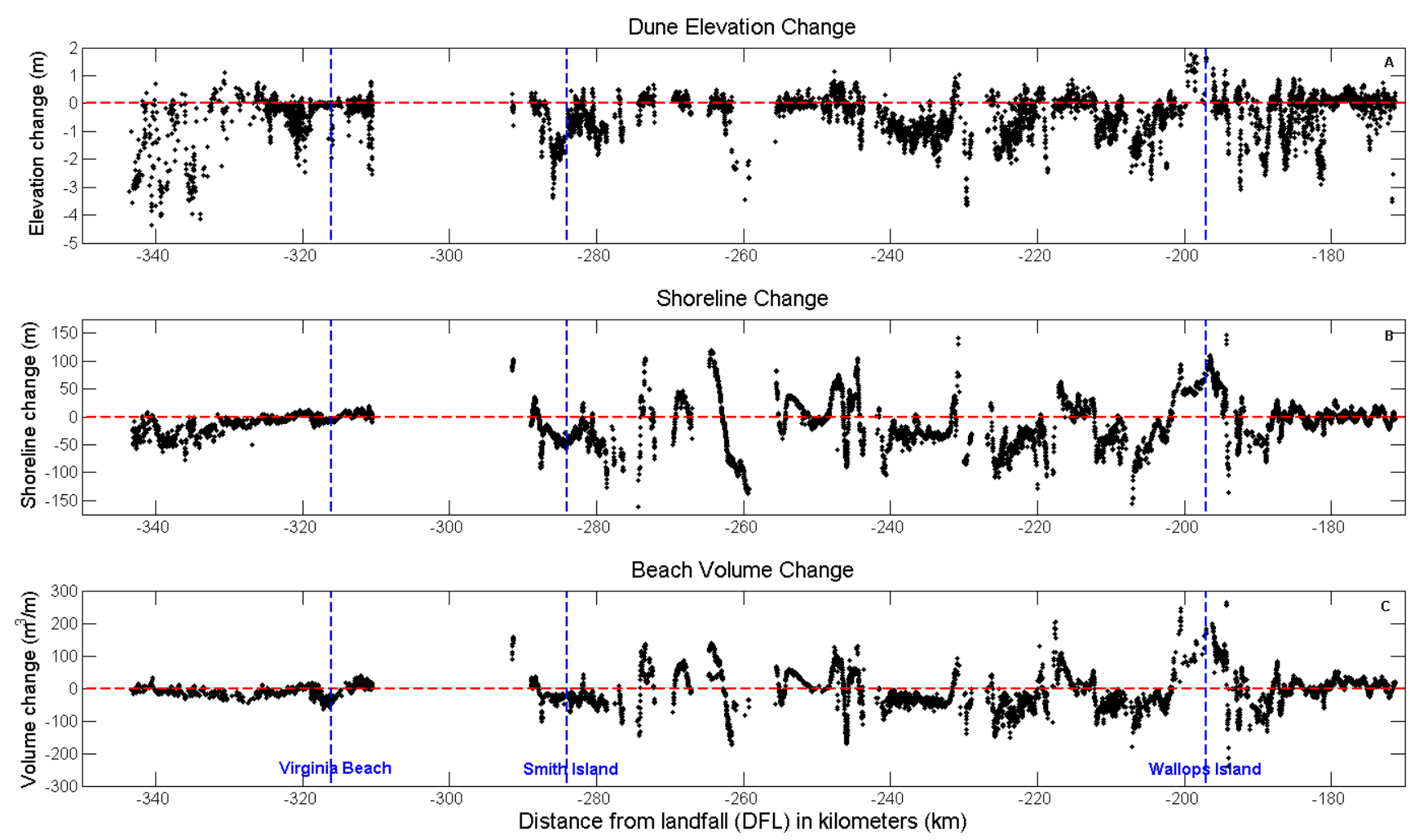

Figure 14. Hurricane Sandy $(A)$ dune-elevation change, $(B)$ shoreline change, and $(C)$ beach-volume change between November 2009 and November 2012 for the Virginia coast. Vertical dashed lines indicate the center of Virginia Beach, Smith Island, and Wallops Island. Measurements are in meters $(\mathrm{m})$, cubic meters per meter $\left(\mathrm{m}^{3} / \mathrm{m}\right)$, and kilometers $(\mathrm{km})$. 
While it is likely that some of the shoreline and volume change observed between the pre- and post-Hurricane Sandy lidar surveys of Virginia's extensive barrier island system north of the mouth of Chesapeake Bay reflects the ongoing evolution of the islands, the impacts of Sandy can be seen, for example, in the landward deposition of sand as dunes were overtopped at Smith Island and elsewhere along the barrier shore (figs. 14A and 15). The sharp shift from shoreline progradation to shoreline retreat $(D F L=-265 \mathrm{~km}$, fig. $14 B)$, however, largely reflects a progressive change in the shape and alignment of Cobb Island that continued between the November 2009 and November 2012 surveys. Similarly, the lidar surveys captured the advance of the shoreline, prior to Sandy, at the northern and southern ends of Hog Island $(D F L=-250 \mathrm{~km}$, Hapke and others, 2010). The large increase in volume, dune elevation, and beach width around Wallops Island is likely due to a beach renourishment project completed in August 2012, between the two lidar surveys of the region (National Aeronautics and Space Administration, 2013).
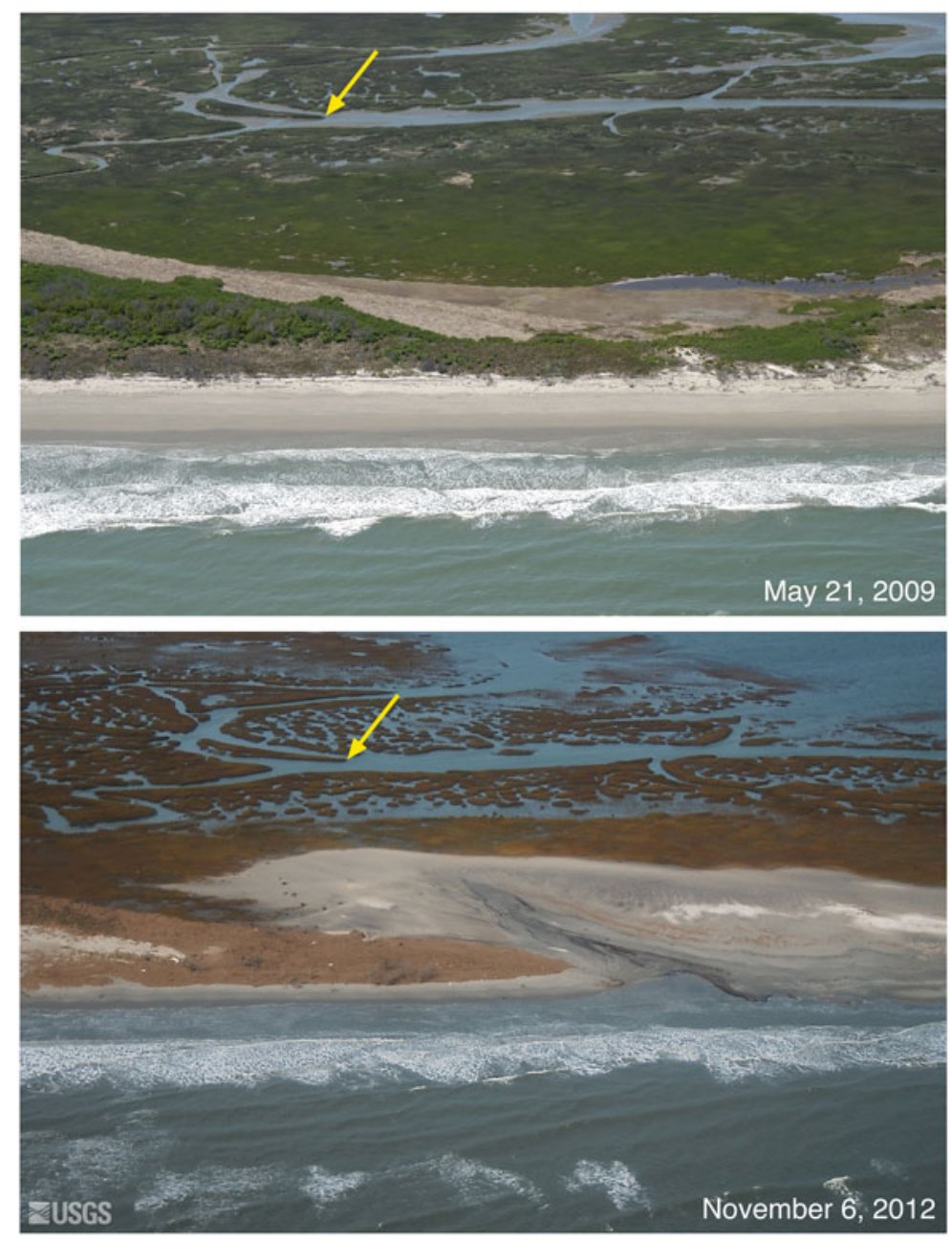

Figure 15. Virginia location 3 (distance from landfall (DFL) -285 kilometers): oblique aerial photographs of Virginia's barrier-island shore. View looking west across Virginia's shore. A higher dune ridge on the left (south) side of this scene suffered erosion, but no overwash. To the right (north), lower dunes were eroded and sand was transported inland as overwash. The yellow arrow in each image points to the same feature. 
North of Wallops Island, the storm response along Assateague Island varied spatially with dune morphology. Much of the southern end of Assateague Island, south of the Assateague Lighthouse (DFL $=-186 \mathrm{~km}$ ), is protected by berms that are less than $2 \mathrm{~m}$ in elevation. The majority of the berms and low dunes experienced erosion and volume loss as sand was transported landward to form large overwash deposits. Breaching occurred through the narrow and low-lying beach just north of Little Toms Cove around $D F L=-190 \mathrm{~km}$ (figs. 16 and 17).

Mid-island, from about $D F L=-180 \mathrm{~km}$ northward across the Virginia/Maryland state border to $D F L \sim-165 \mathrm{~km}$ (fig. 14A), dunes are larger, averaging $4.5 \mathrm{~m}$ in height. Elevated water levels and storm-driven waves eroded the dune face causing scarping along this extent of the Assateague coastline but dune height remained intact. Overwash occurred in limited areas where previous storms cut through the line of dunes. 

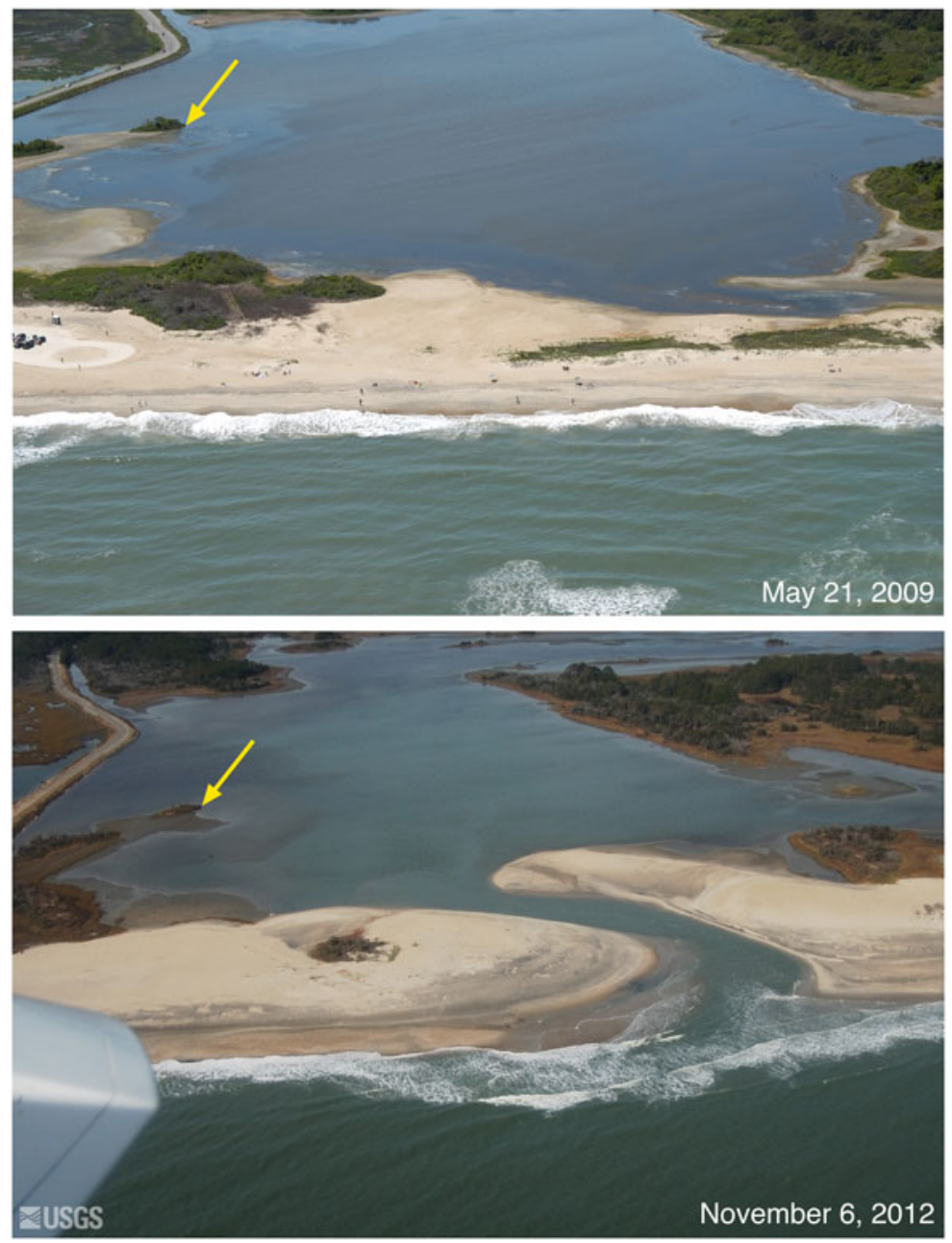

Figure 16. Virginia location 4 (distance from landfall (DFL) -188 kilometers): oblique aerial photographs of Assateague Island, Virginia. View looking west across the shore of the Chincoteague National Wildlife Refuge. Overwash deposits have transported sand inland across the island and into the lagoon behind it. The beach and low dunes have been breached. The yellow arrow in each image points to the same feature. 

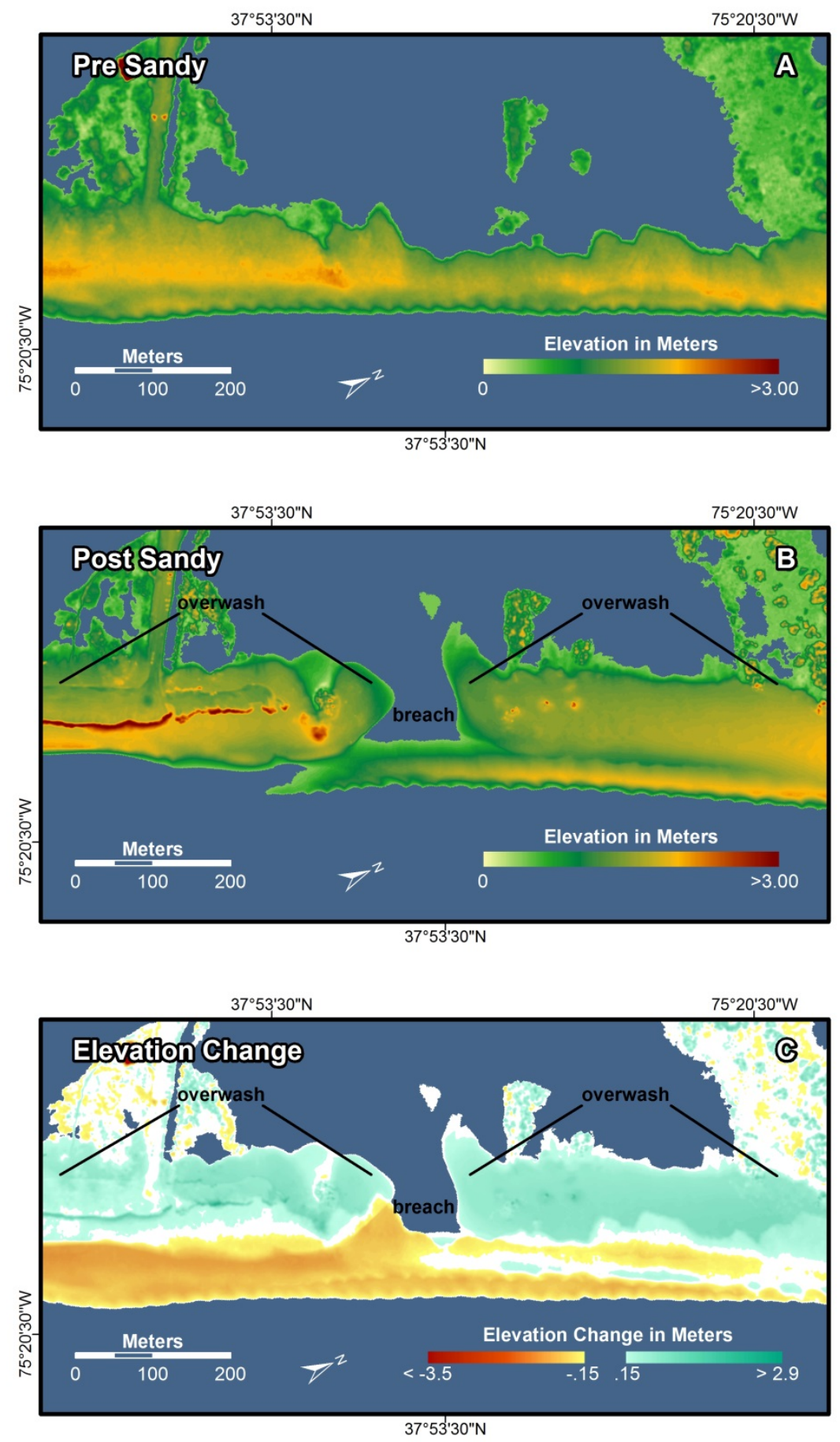

Figure 17. Three-dimensional lidar topography before (November 2009; A) and after (November 2012; B) Hurricane Sandy; and elevation change $(C)$ at location 4 (fig. 8), Chincoteague National Wildlife Refuge, Assateague Island, Virginia. The pre-storm map shows that this part of the island is very low-lying (elevations less than $2 \mathrm{~m}$ ) and narrow and has been overwashed by earlier storms. During Hurricane Sandy, not only was there extensive overwash and deposition, but an island breach occurred. In the post-storm map there is evidence that the breach is beginning to fill in naturally, which is not evident in the photo comparisons. To the left (south) of the breach, road crews pushed sand off the roadway into a line of piled sand. 


\section{Maryland and Delaware}

The majority Assateague Island's northern end, from $D F L=\sim-163 \mathrm{~km}$ north to Ocean City Inlet $(D F L \sim-136 \mathrm{~km}$ ), was fronted by a $2 \mathrm{~m}$ high berm prior to Hurricane Sandy. Storm waves and elevated water levels destroyed the majority of this low dune structure, carrying sand inland (figs. 18A, 19 and 20 ) and creating overwash deposits in the bay behind the island in narrow, low-lying places. In the few places along this stretch where a dune exceeded the $2 \mathrm{~m}$ high berm, the dune crest remained intact and these locations appear as near-zero dune erosion in figure 18A. A location with positive shoreline change and correlated volume increase near the Ocean City Inlet is associated with the exaggeration of a beach cusp south of the jetty on the northernmost point of Assateague Island. 

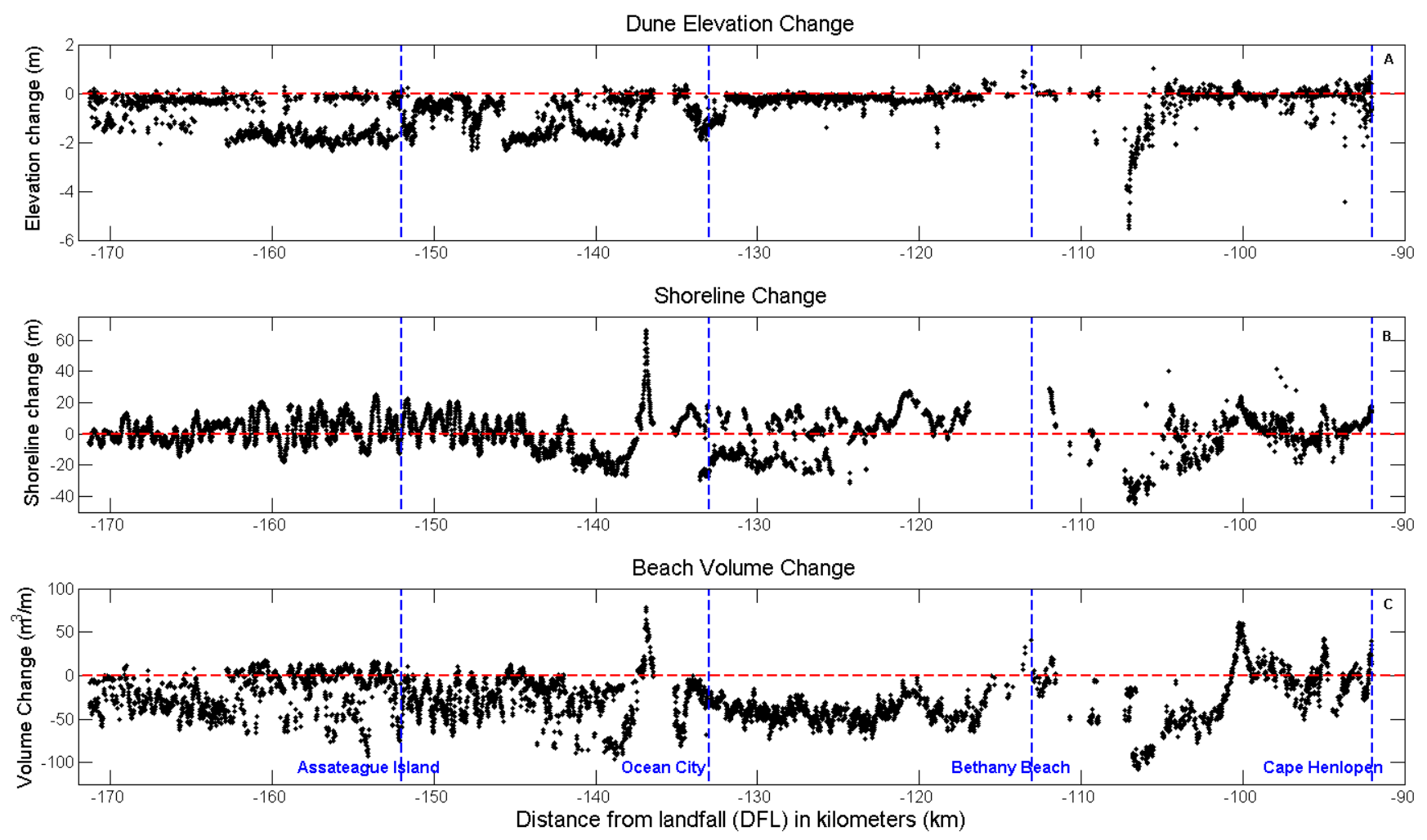

Figure 18. Hurricane Sandy $(A)$ dune-elevation change, $(B)$ shoreline change, and $(C)$ beach-volume change between September 2010 and November 2012 for the Maryland and Delaware coasts. Vertical dashed lines indicate the center of Assateague Island, Ocean City, Bethany Beach, and Cape Henlopen. Measurements are in meters $(\mathrm{m})$, cubic meters per meter $\left(\mathrm{m}^{3} / \mathrm{m}\right)$, and kilometers $(\mathrm{km})$. 

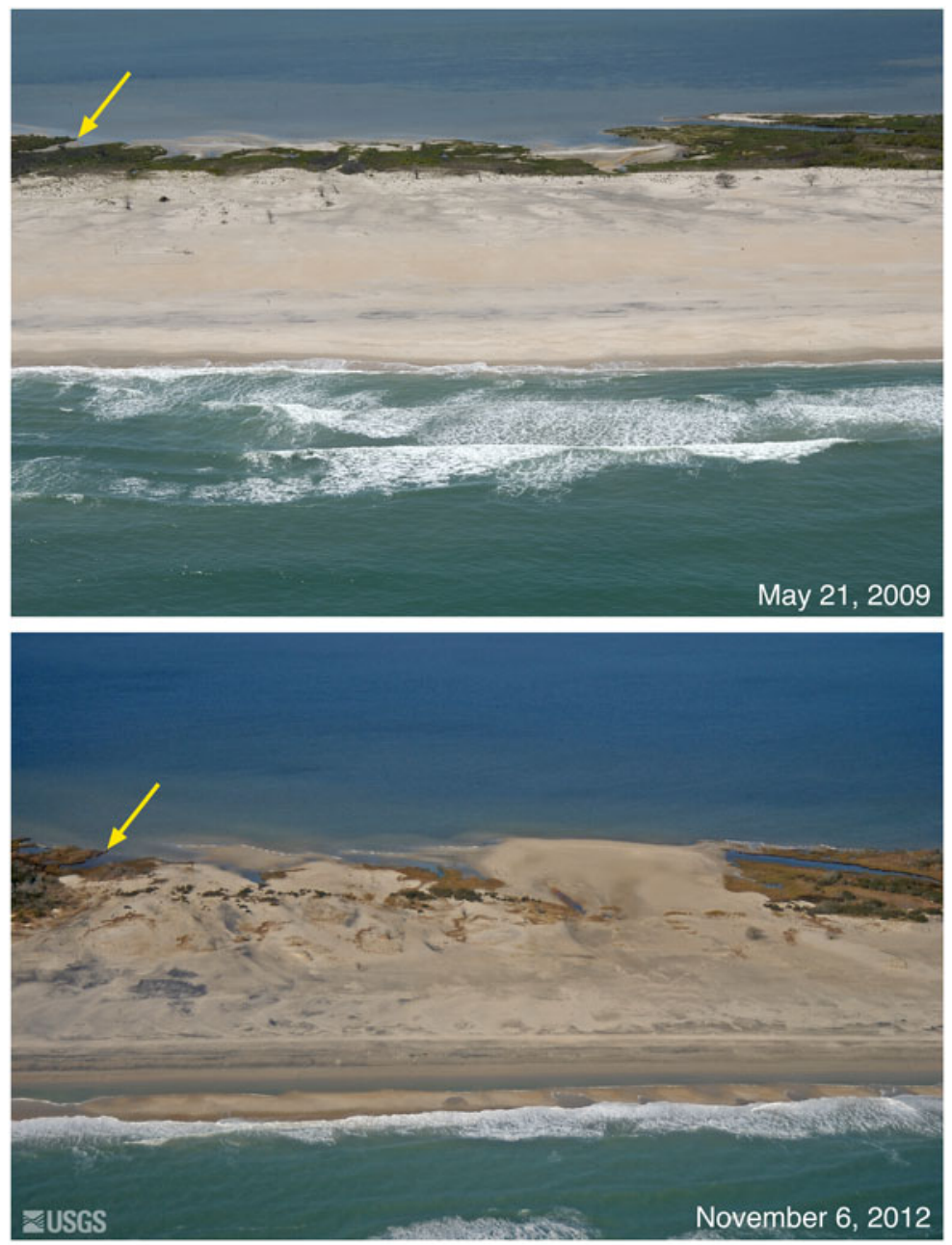

Figure 19. Maryland/Delaware location 5 (distance from landfall (DFL) -144 kilometers): oblique aerial photographs of Assateague Island, Maryland. View looking northwest across the Maryland shore. Storm waves and surge overtopped the low dunes in this location, and overwash moved sand across the island and into the bay. The yellow arrow in each image points to the same feature. 

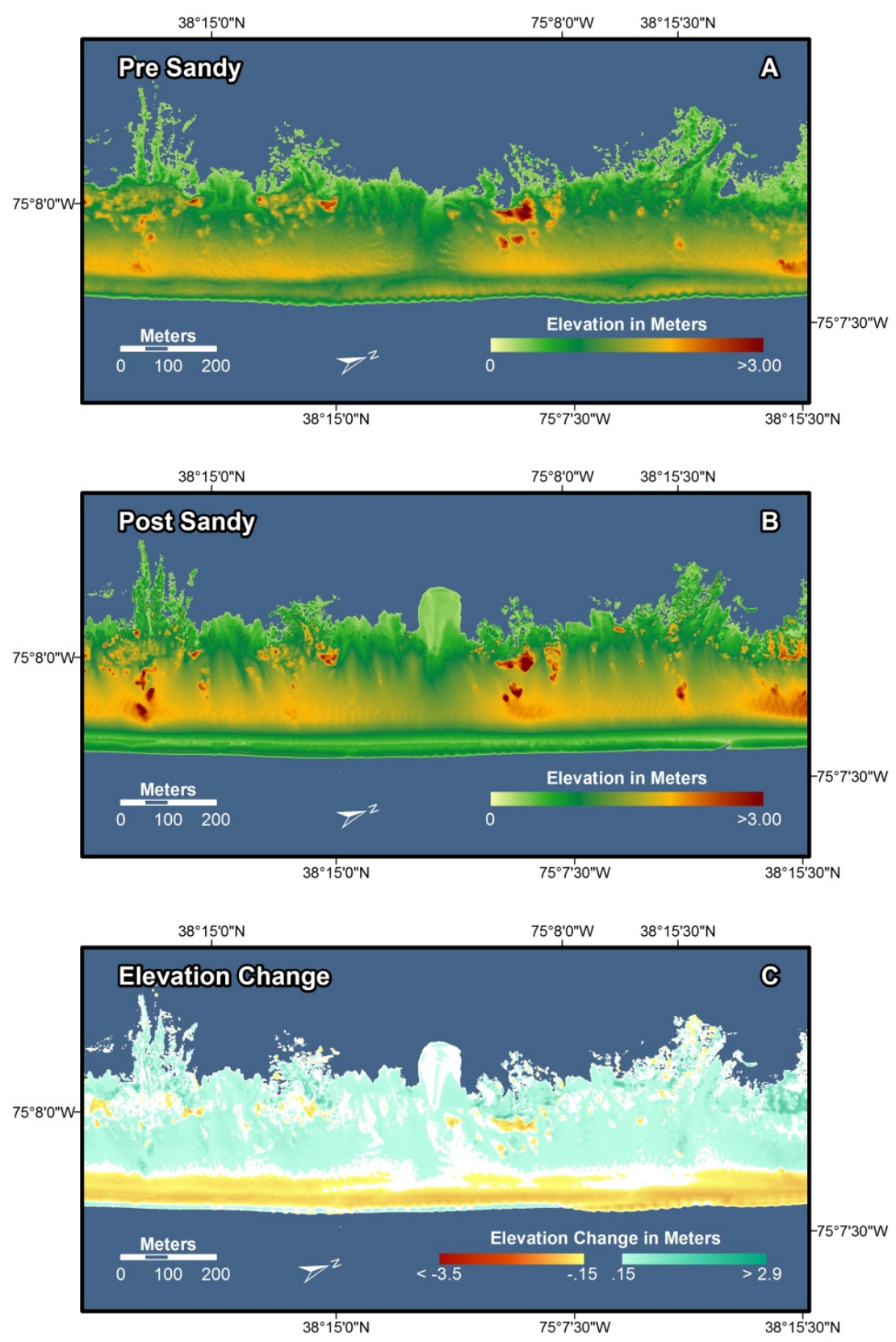

Figure 20. Three-dimensional lidar topography before (November 2009; $A$ ) and after (November 2012; B) Hurricane Sandy; and elevation change $(C)$ at location 5 (fig. 8), Assateague Island, Maryland. The pre-storm map shows a narrow, low-lying area that crosses the island from front to back. In the post-storm and difference maps, waves and surge deposited sand into the bay as an overwash fan and widened the island at this location. Beach erosion and overwash deposition occurred uniformly along this section of the barrier island. 
While the dunes along the developed coastline of Maryland from Ocean City Inlet northward remained largely intact (fig. 18A), waves and surge generated by Sandy eroded and narrowed the beaches (fig. 18B-C). The greatest amount of dune erosion in Maryland, north of Assateague Island, occurred north of the Ocean City inlet where a 2-m dune elevation reduction was observed and the Ocean City Fishing Pier was damaged.

Between October 2011 and February 2012, a renourishment project was completed that spanned the beaches from Fenwick Island, Del. $(D F L=-121 \mathrm{~km})$, north to Lewes Beach just south of Cape Henlopen. Sand was pumped onto the face of the beach — increasing beach width — and dunes were constructed (Retzler, 2013). Despite the addition of sand, Delaware beaches from Bethany Beach and the Delaware Seashore State Park (figs. 21 and 18A-C) to just south of Dewey Beach (DFL -100 km) suffered significant dune erosion, volume loss and shoreline retreat. Areas where the created dunes and widened beach system remained intact after the passage of Sandy appear as positive shoreline change (fig. 18B) and increased volume (fig. 18C). 

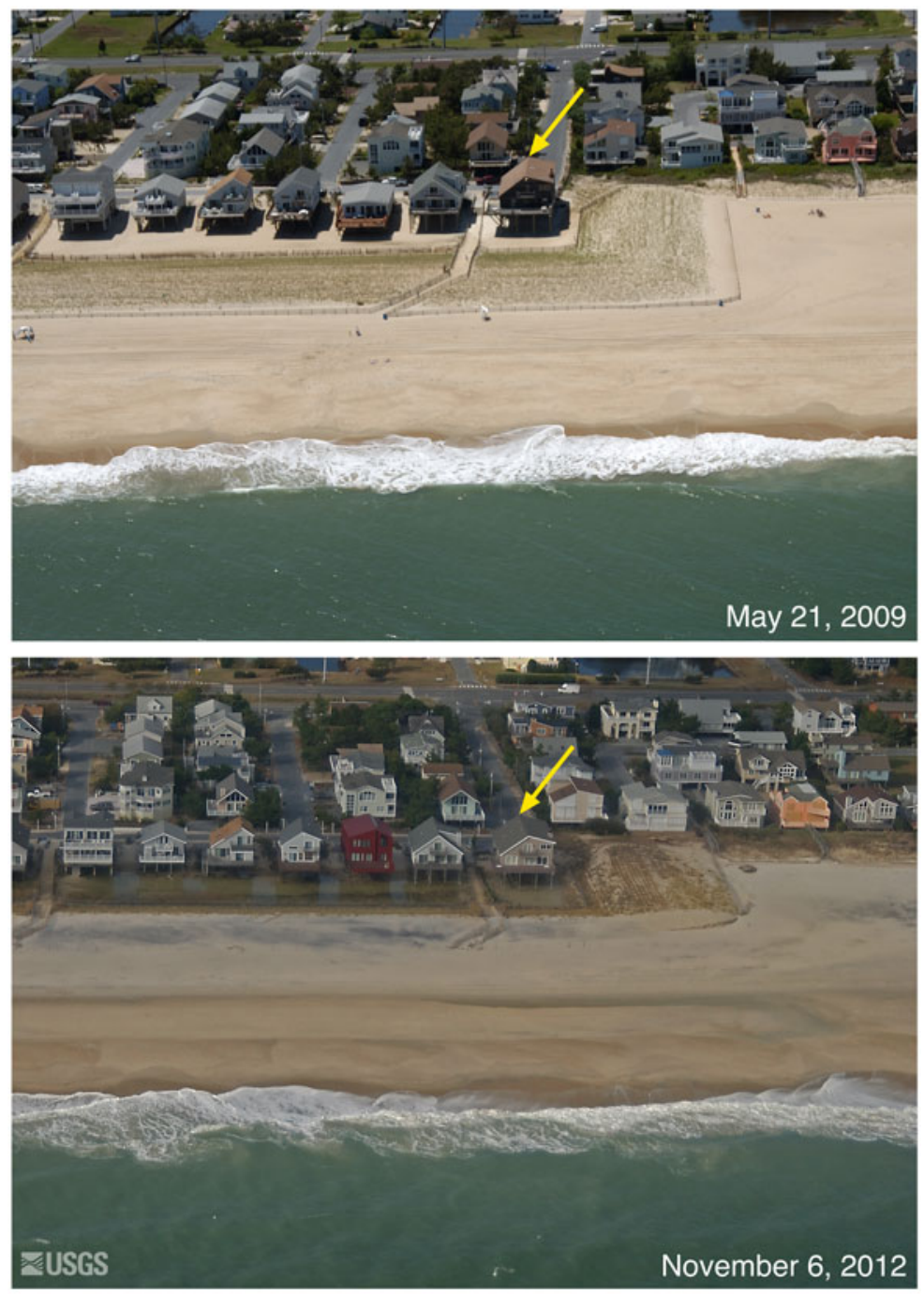

Figure 21. Maryland/Delaware location 6 (distance from landfall (DFL) -115 kilometers): oblique aerial photographs of South Bethany, Delaware. View looking west across the Delaware shore. Storm waves and surge eroded the low dune seen in the upper image (area fenced off and planted with grass). The yellow arrow in each image points to the same feature.

\section{New Jersey}

Destructive waves and storm surge associated with Sandy severely eroded the beach and dune systems that represented, in many places, the first line of defense for the New Jersey coastline. The majority of the New Jersey coast from Brigantine, where Sandy made landfall, northward experienced severe dune erosion of anywhere from 2 to $6 \mathrm{~m}$ vertical loss (fig. 22A). Along the undeveloped barrier coast from Brigantine to Beach Haven (DFL $16 \mathrm{~km}$; fig. 22A), dunes that averaged $3.2 \mathrm{~m}$ in peak elevation pre-storm were eroded in height by an average of $1.7 \mathrm{~m}$ (figs. 23 and 24). The dunes along New Jersey's Island Beach State Park $(D F L=47-60 \mathrm{~km})$ were also severely impacted with an average elevation loss of $1.4 \mathrm{~m}$ and a mean loss of sand volume from the beach of 69.0 cubic meters per meter $\left(\mathrm{m}^{3} / \mathrm{m}\right)$ along the barrier-island dune system. Waves atop elevated water levels eroded the face of the dunes, resulting in dune scarping and breaching of the dune line in places allowing waves to carry sand inland and deposit sand on roads and in parking lots (fig. 25). 

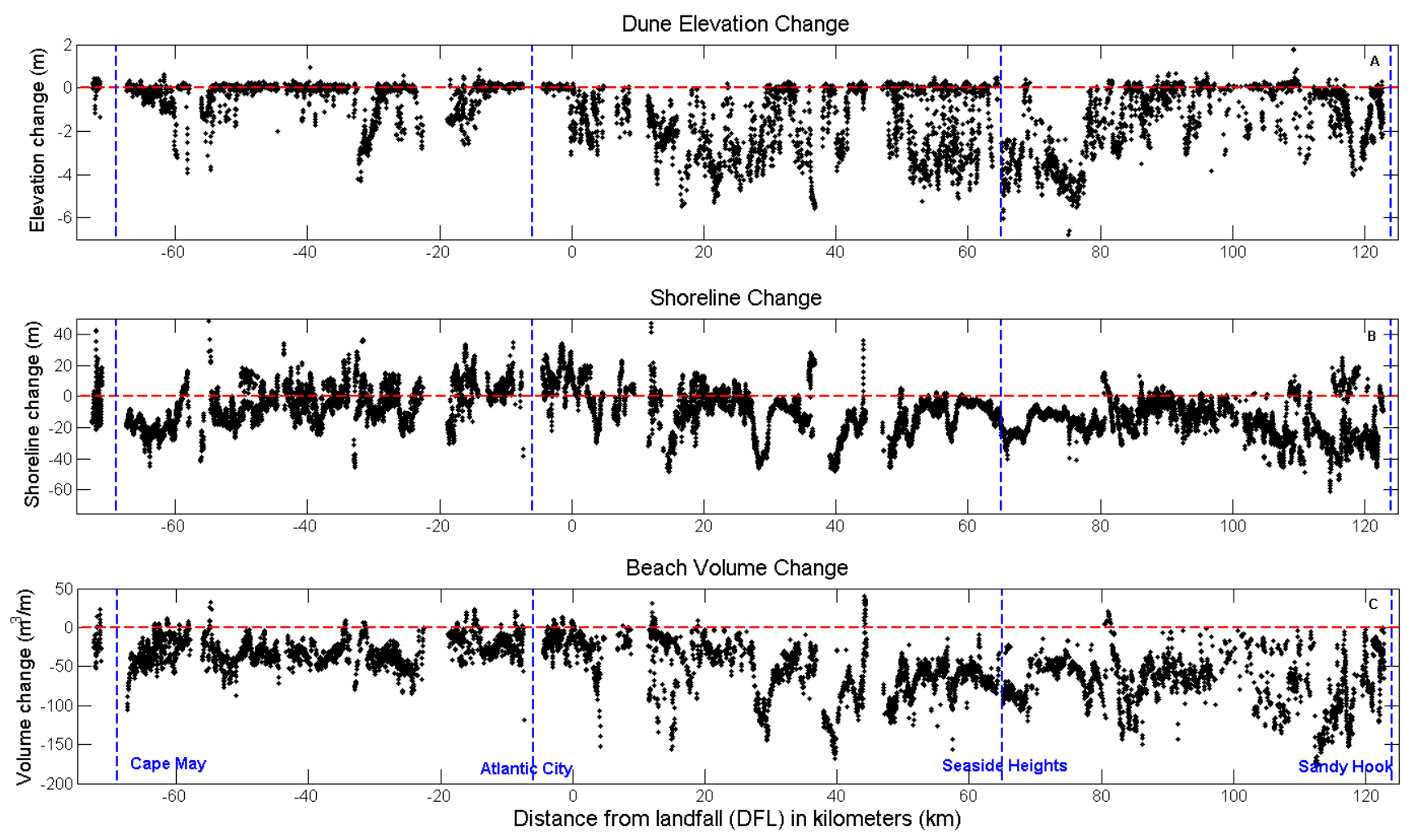

Figure 22. Hurricane Sandy $(A)$ dune-elevation change, $(B)$ shoreline change, and $(C)$ beach-volume change between October and November 2012 for the New Jersey coast. Vertical dashed lines indicate the center of Cape May, the communities of Atlantic City and Seaside Heights, and Sandy Hook, New Jersey. Measurements are in meters $(\mathrm{m})$, cubic meters per meter $\left(\mathrm{m}^{3} / \mathrm{m}\right)$, and kilometers $(\mathrm{km})$. 

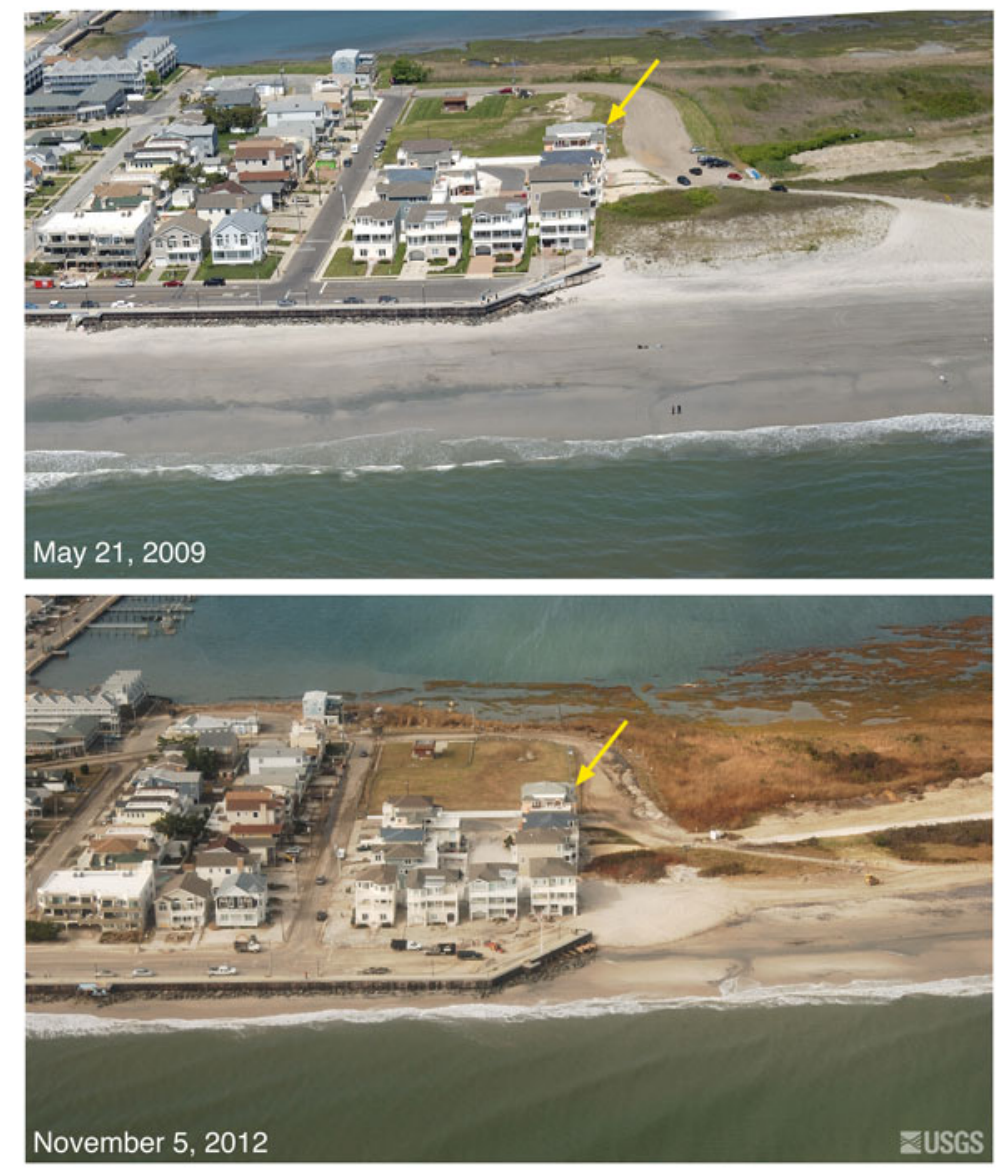

Figure 23. New Jersey location 7 (distance from landfall (DFL) 1 kilometer): oblique aerial photographs of Brigantine, New Jersey. View looking northwest across the New Jersey shore. Storm waves and surge eroded the beach and exposed the seawall. Overwash of the seawall is indicated by sand deposited on the street. Low dunes on the eastern flank of the seawall were eroded. The yellow arrow in each image points to the same feature. 

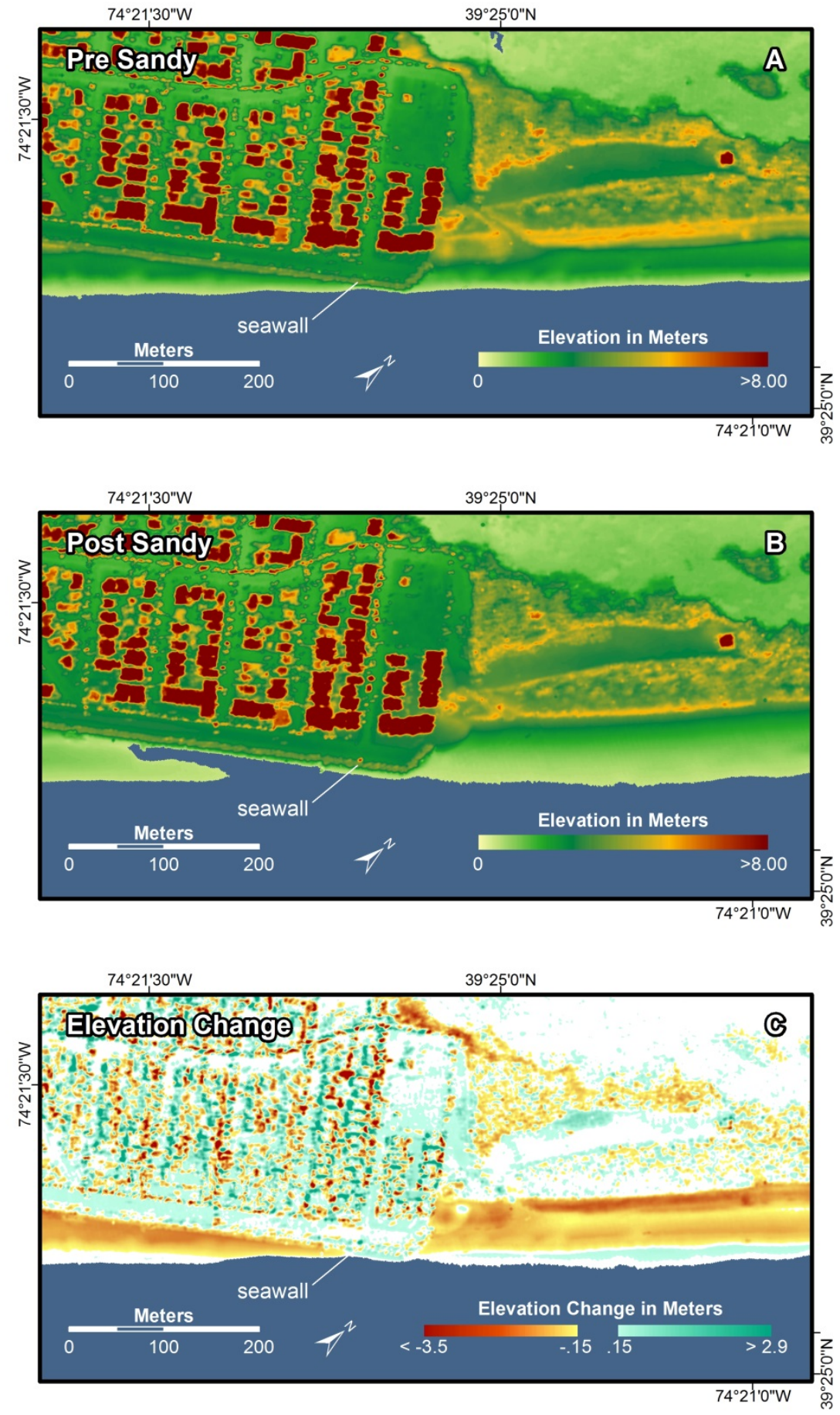

Figure 24. Three-dimensional lidar topography before (October 2012; $A$ ) and after (November 2012; $B$ ) Hurricane Sandy; and elevation change (C) at location 7 (fig. 8), Brigantine, New Jersey. This area consists of a developed area on the left and an undeveloped area on the right. The beach in front of the seawall on the developed side was eroded, and storm surge and waves overwashed the seawall depositing sand on the island. On the undeveloped side, the seaward side of the dunes and the beach were eroded, resulting in a flatter and wider beach. 

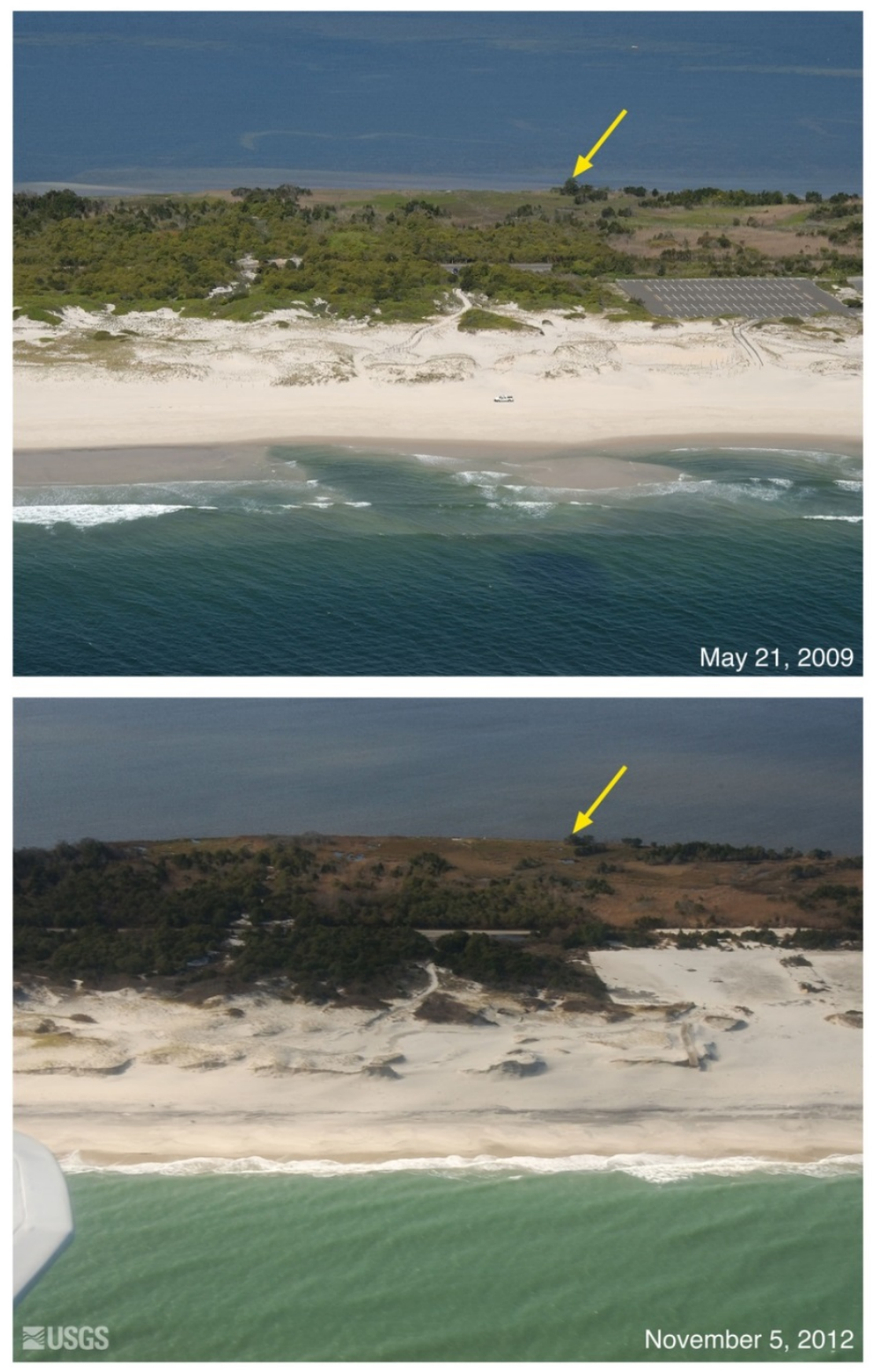

Figure 25. New Jersey location 8 (distance from landfall (DFL) 54 kilometers): oblique aerial photographs of Island Beach State Park, New Jersey. View looking west across the New Jersey shore. Storm surge and waves eroded the front face of the dunes and overwash is indicated by sand deposited in the parking lot behind the beach. The yellow arrow in each image points to the same feature. 
The greatest impacts from Sandy were observed along the shoreline from the northern boundary of Island Beach State Park north through Mantoloking, N.J. (DFL $=76 \mathrm{~km})$, encompassing the communities of Seaside Park, Seaside Heights, Ortley Beach, Lavallette, Dover Beaches North, Normandy Beach and Mantoloking. Dunes here experienced an average of $2.7 \mathrm{~m}$ elevation loss. In Seaside Heights, for example, maximum dune-elevation erosion of $7 \mathrm{~m}$ was observed $(D F L=75 \mathrm{~km})$ and many oceanfront houses were severely damaged (figs. 26, 27 and 22A). Storm waves and surge destroyed the Seaside Heights Pier and the boardwalk in places, eroded the beach, overwashed dunes and washed sand inland, damaging or destroying homes. In Mantoloking, waves and surge breached the narrow island in several locations, cutting through roads and homes and washing houses into Barnegat Bay (figs. 28 and 29). 

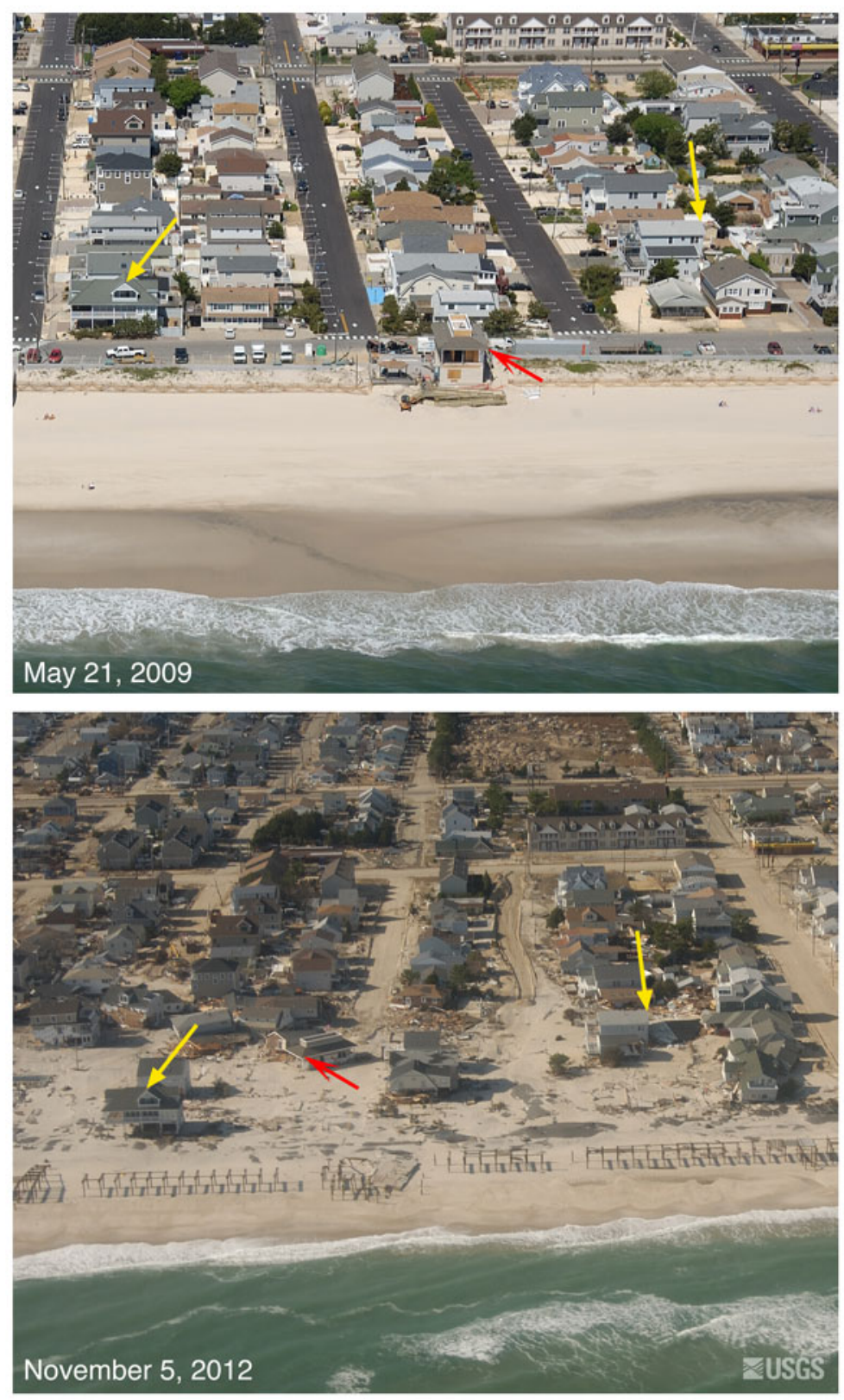

Figure 26. New Jersey location 9 (distance from landfall (DFL) 66 kilometers): oblique aerial photographs of Seaside Heights, New Jersey. View looking west across the New Jersey shore. Storm waves and surge destroyed the dunes and boardwalk and deposited the sand on the island, covering roads. The red arrow points to a building that was washed from its foundation and moved about a block away from its original location. The yellow arrows in each image point to the same features. 

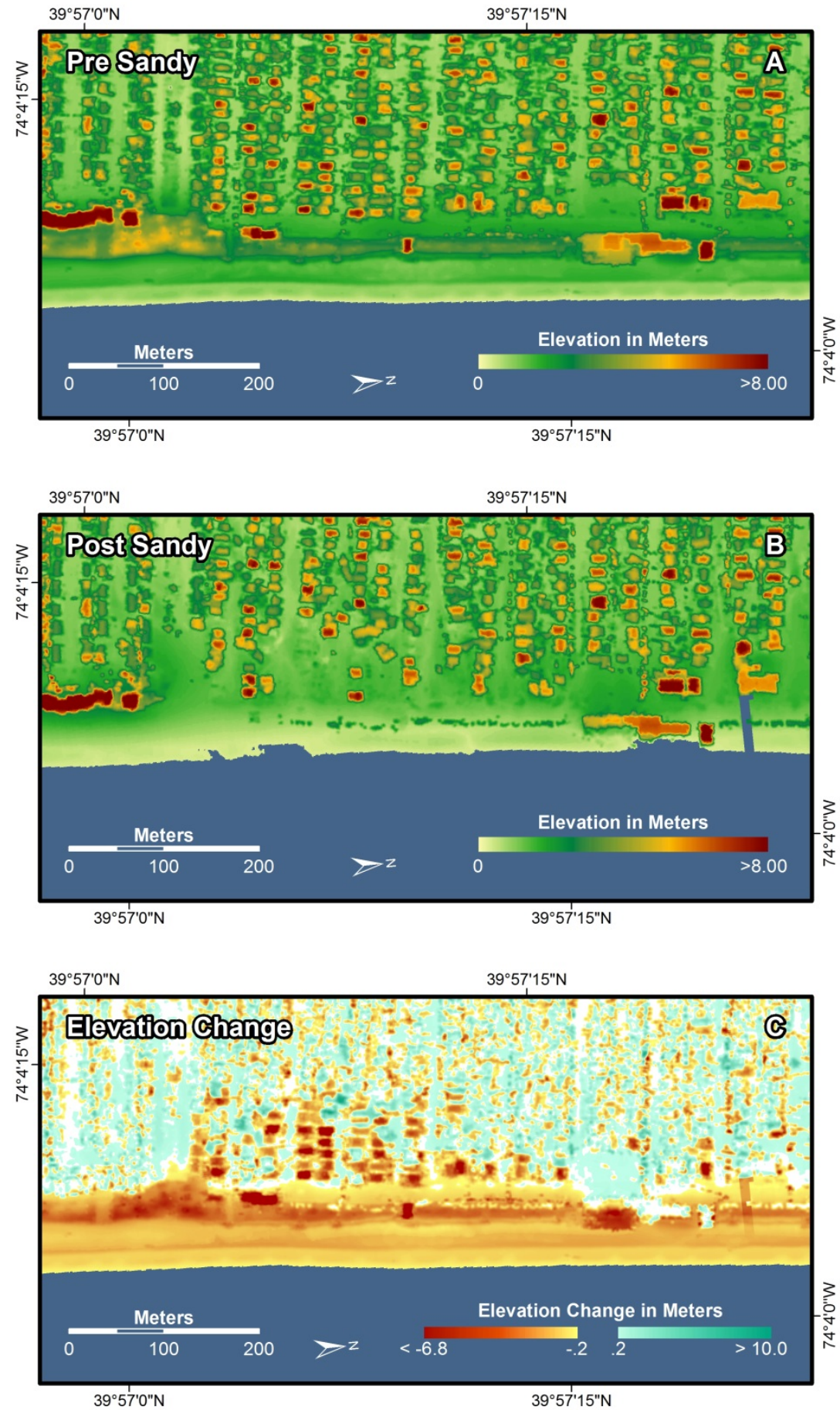

Figure 27. Three-dimensional lidar topography before (October 2012; $A$ ) and after (November 2012; $B$ ) Hurricane Sandy; and elevation change $(C)$ at location 9 (fig. 8), Seaside Heights, New Jersey. Storm surge and waves eroded the beach, overwashed the dunes, and deposited sand on the island. The boardwalk, which had been built on the dunes, and several buildings were destroyed. The line of dark green features, indicating higher elevations in the post-Sandy image, shows the remnants of the boardwalk. 

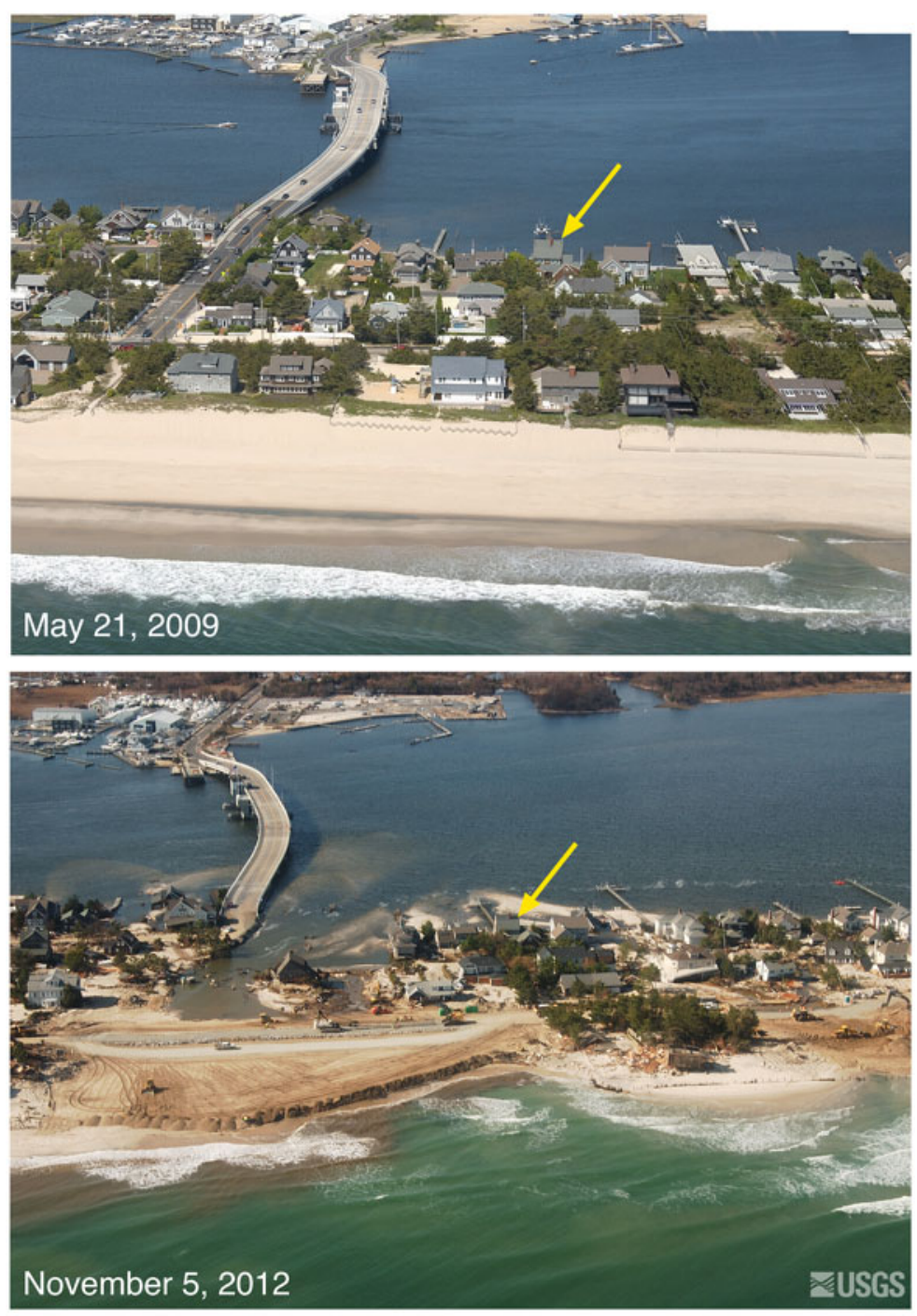

Figure 28. New Jersey location 10 (distance from landfall $(D F L) \sim 75$ kilometers): oblique aerial photographs of Mantoloking, New Jersey. View looking west across the New Jersey shore. Storm waves and surge cut through the barrier island at Mantoloking, New Jersey, eroding a wide beach, destroying houses and roads, and depositing sand onto the island and into the back-bay. Construction crews with heavy machinery are seen clearing sand from the rows, filling the breach, and pushing sand seaward to build a wider beach and protective berm just days after the storm. The yellow arrow in each image points to the same feature. 

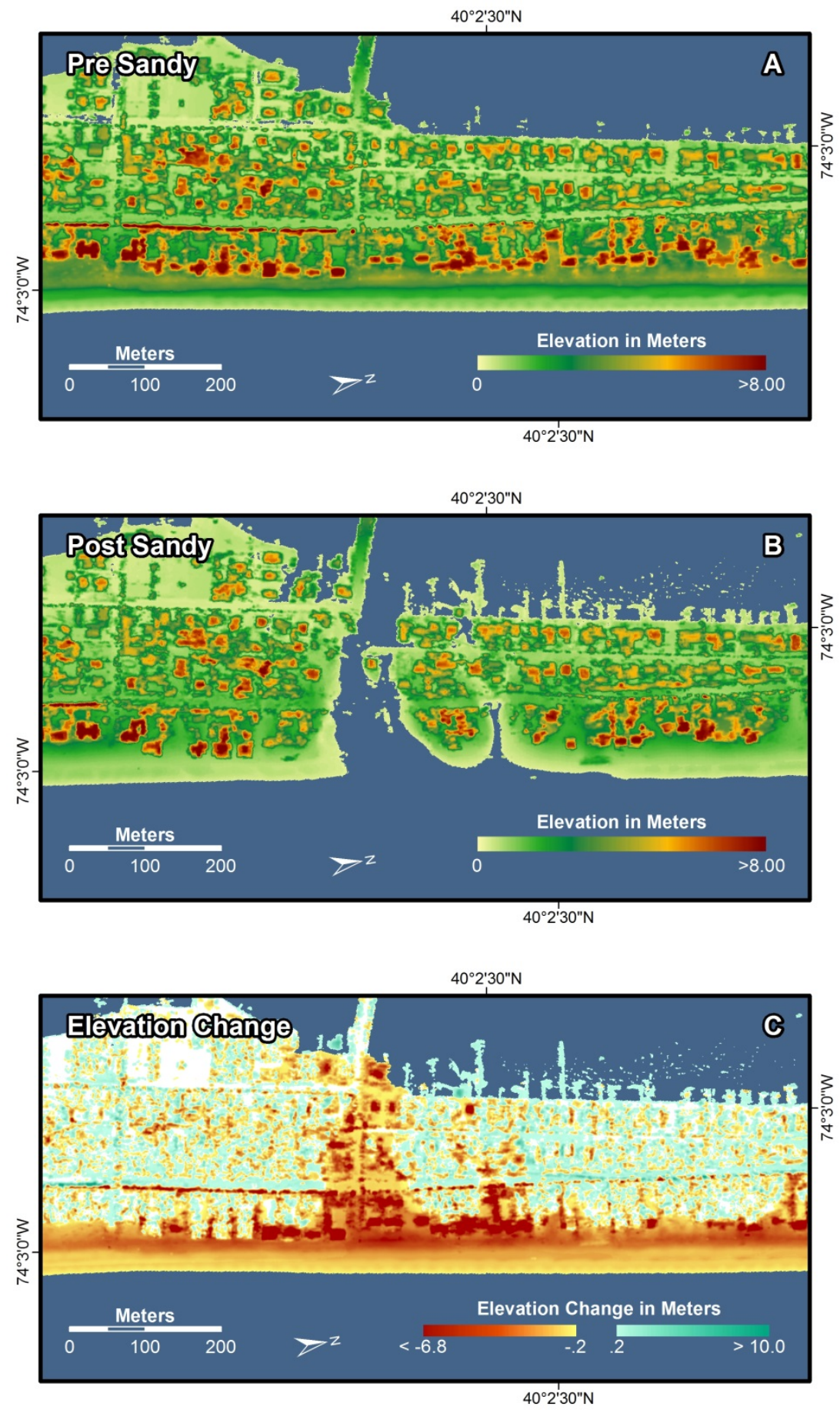

Figure 29. Three-dimensional lidar topography before (October 2012; $A$ ) and after (November 2012; $B$ ) Hurricane Sandy; and elevation change (C) at location 10 (fig. 8), Mantoloking, New Jersey. At this location, storm surge and waves eroded the beach and dunes and a breach cut through the approximately 250 -meter- $(\mathrm{m})$ wide island, destroying houses and roads. Overwash deposition occurred in many areas. Note that the lidar survey was conducted immediately after the storm, whereas the photo survey was conducted a few days later after the breach was filled. 
The positive shoreline change and volume increase visible approximately $45 \mathrm{~km}$ north of landfall (fig. 22B-C) is associated with the storm-induced progradation of the beach just south of the Barnegat Light. Near Atlantic City $(D F L=37 \mathrm{~km}$; fig. 22B), the positive shoreline change resulted from a swash bar fusing with the beach as sand moved back onshore as part of the natural beach recovery process after the storm.

\section{New York}

Some of the regions of New York hardest hit by Hurricane Sandy's storm surge include the highly developed communities of Coney Island, the Rockaway Peninsula, and Long Beach barrier island $(D F L=131-145 \mathrm{~km}$; fig. 30). Waves and surge attacked dunes averaging $4.3 \mathrm{~m}$ in elevation in this region (Stockdon and others, 2013), overtopping the dunes and transporting sand into coastal communities (fig. 31), and causing an average of $1.4 \mathrm{~m}$ of vertical dune erosion (fig. 30A). The unexpected spike of increased sand volume and positive shoreline change (fig. 30B-C), visible at $D F L \sim$ $140 \mathrm{~km}$, corresponds to a narrow stretch of beach on the eastern end of the Rockaway Peninsula, south of Edgemere, where surge and waves eroded the beach back to the boardwalk and destroyed sections of the boardwalk. Immediately after the storm, work crews began pumping sand back to this portion of the coastline. The buildup of sand indicated by the post-storm lidar survey captures these restoration activities (http://coastal.er.usgs.gov/hurricanes/sandy/post-storm-photos/obliquephotos.html/). 
Dune Elevation Change

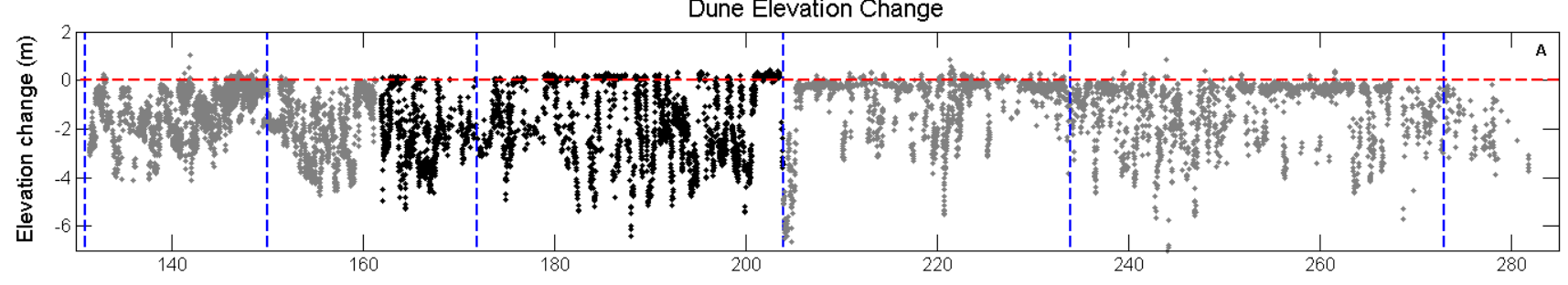

Shoreline Change

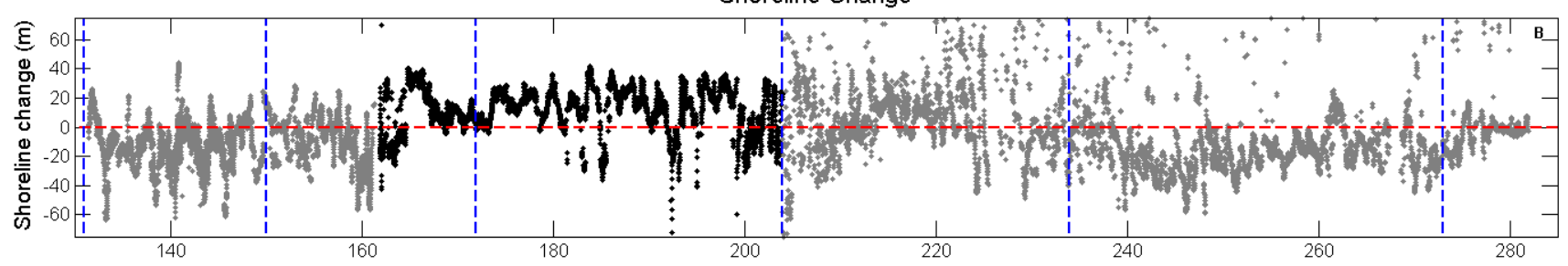

Beach Volume Change

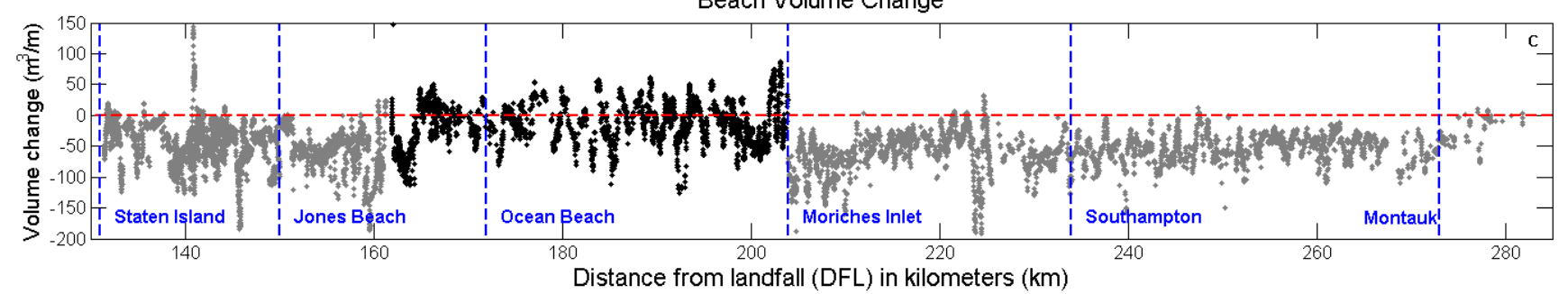

Figure 30. Hurricane Sandy $(A)$ dune-elevation change, $(B)$ shoreline change, and $(C)$ beach-volume change between May 2012 and November 2012 for the Fire Island, New York, coast (black) and between August 2010 and November 2012 for the rest of Long Island, New York (gray).

Vertical dashed lines indicate the location of Staten Island, the centers of Jones and Ocean Beaches, the locations of Moriches Inlet, Fire Island, Southampton, and Montauk. Measurements are in meters $(\mathrm{m})$, cubic meters per meter $\left(\mathrm{m}^{3} / \mathrm{m}\right)$, and kilometers $(\mathrm{km})$. 

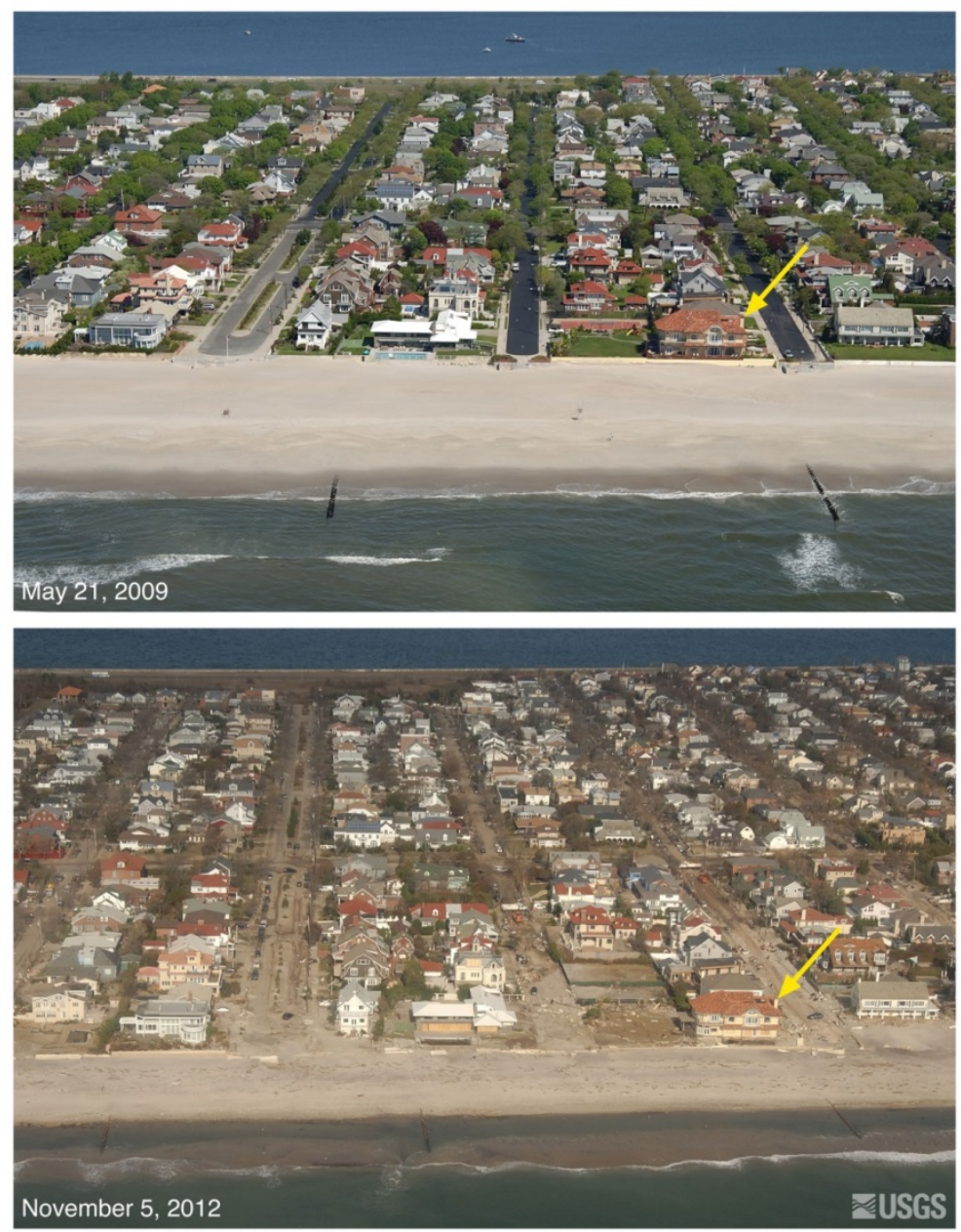

Figure 31. New York location 11 (distance from landfall (DFL) 166 kilometers): oblique aerial photographs of Neponsit, New York. The view is looking northwest across Rockaway Peninsula, adjacent to New York Harbor. Sand was washed from the beach into the streets, and toward the bayside of the island. Several rows of oceanfacing houses were destroyed or damaged. The yellow arrow in each image points to the same feature.

Along Fire Island, N.Y., a mean dune-height erosion of $2 \mathrm{~m}$ was observed with dune erosion as high as $5 \mathrm{~m}$ in many places (fig. 30A). Nearly half of the island's dunes experienced overwash (Hapke and others, 2013) resulting in deposition of sand landward and an overall flattening of beach topography. For example, overwash of the dunes at Ocean Bay Park, just east of Ocean Beach, N.Y., resulted in the transport of large volumes of sand inland from the beach system, severe decrease of dune height (figs. 32, 33 and 30A,C) and significant property damage. Breaching occurred in several locations along Fire Island, including at Old Inlet (the location of breaching during previous storms), approximately $3 \mathrm{~km}$ west of the William Floyd Parkway (fig. 34), DFL $=192 \mathrm{~km}$, where volume loss and shoreline retreat are apparent (figs. 30B, C and 35). Positive shoreline change observed along much of Fire Island (fig. 30B) is evidence of recovery of the seaward-edge of the beach system immediately following the passage of the storm. A more detailed analysis of coastal changes occurring on Fire Island can be found in Hapke and others (2013). 

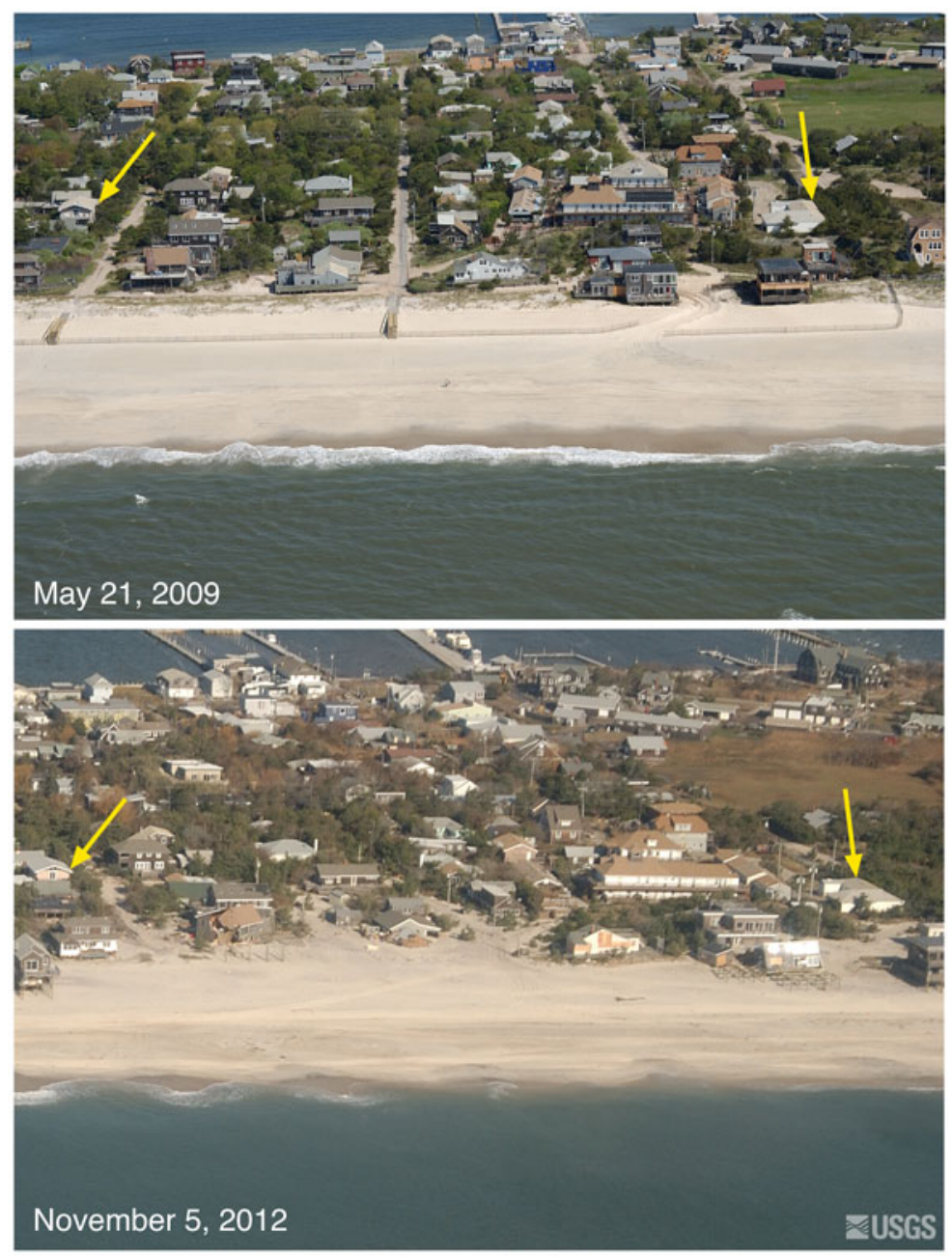

Figure 32. New York location 12 (distance from landfall (DFL) 173 kilometers): oblique aerial photographs of Ocean Bay Park, Fire Island, New York. The view is looking northwest across Fire Island towards Great South Bay. Overwash from the beach and narrow dunes carried sand inland towards the interior and bayside of the island, and numerous houses were destroyed or severely damaged. The yellow arrows in each image point to the same features. 

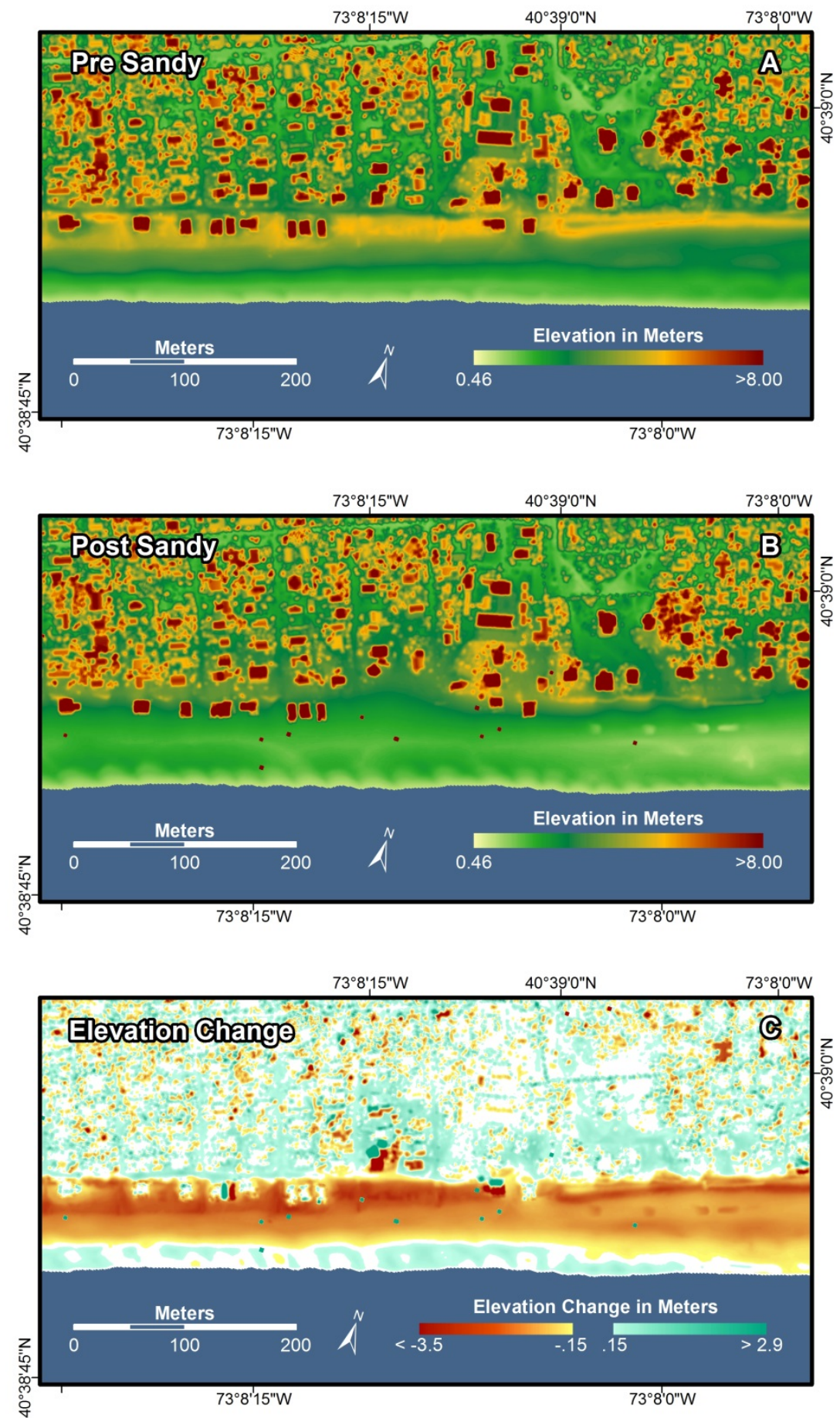

Figure 33. Three-dimensional lidar topography before (May 2012; A) and after (November 2012; B) Hurricane Sandy; and elevation change $(C)$ of location 12 (fig. 8), Ocean Bay Park, Fire Island, New York. Extensive erosion occurred here, removing sand from a 50-meter- $(\mathrm{m})$ wide swath of the beach and dunes. Overwash from the beach and narrow dunes carried sand inland toward the interior and bayside of the island, and numerous houses were destroyed or severely damaged. 

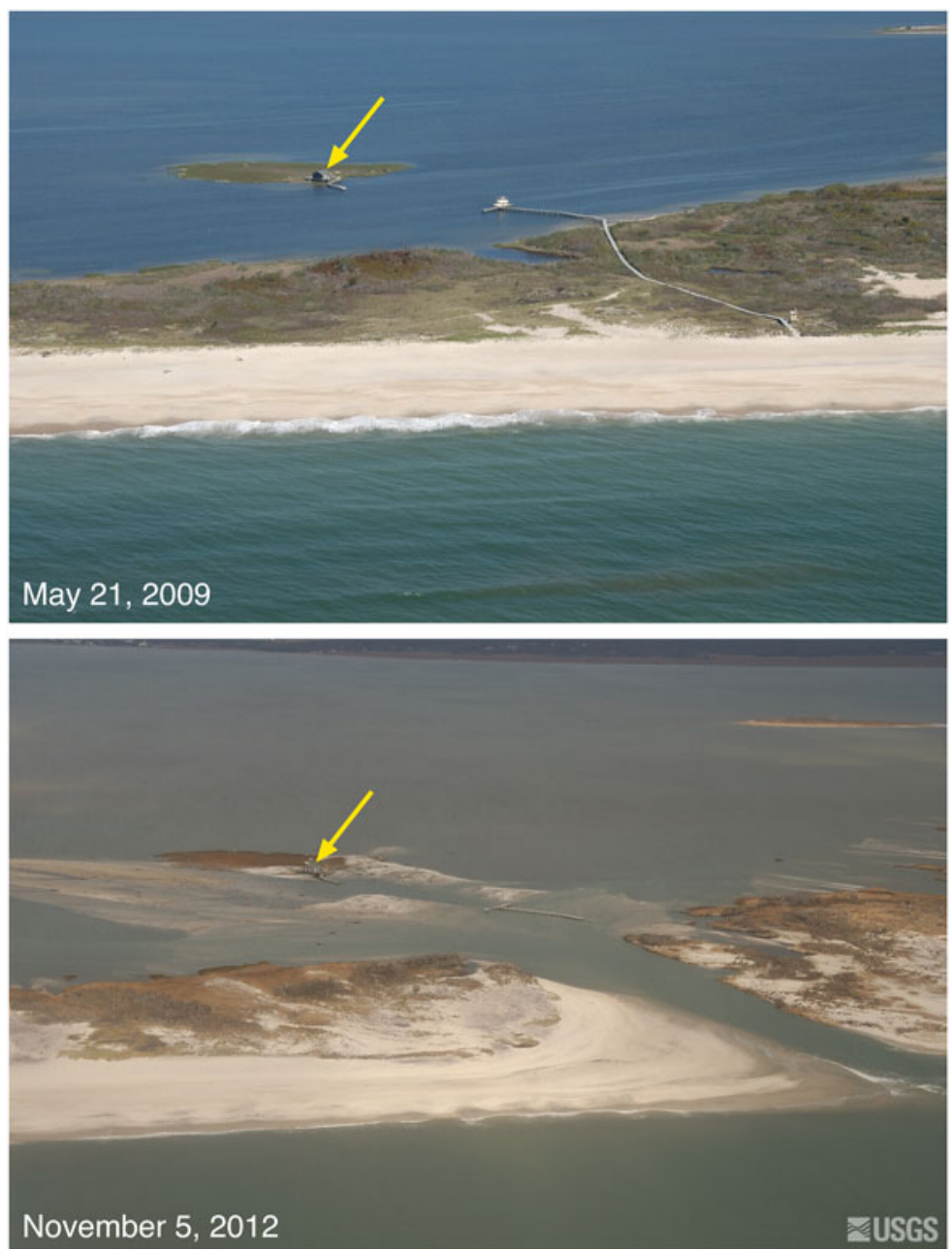

Figure 34. New York location 13 (distance from landfall (DFL) 192 kilometers): oblique aerial photographs of Pelican Island and Fire Island, New York. The view is looking northwest across Fire Island toward Great South Bay. This location is within Fire Island National Seashore near Old Inlet - a very narrow portion of the island named as such for previous breaching during large storms. The island breached during Sandy, creating a new inlet. Despite the breach, the fishing shack (yellow arrow) remained standing. 

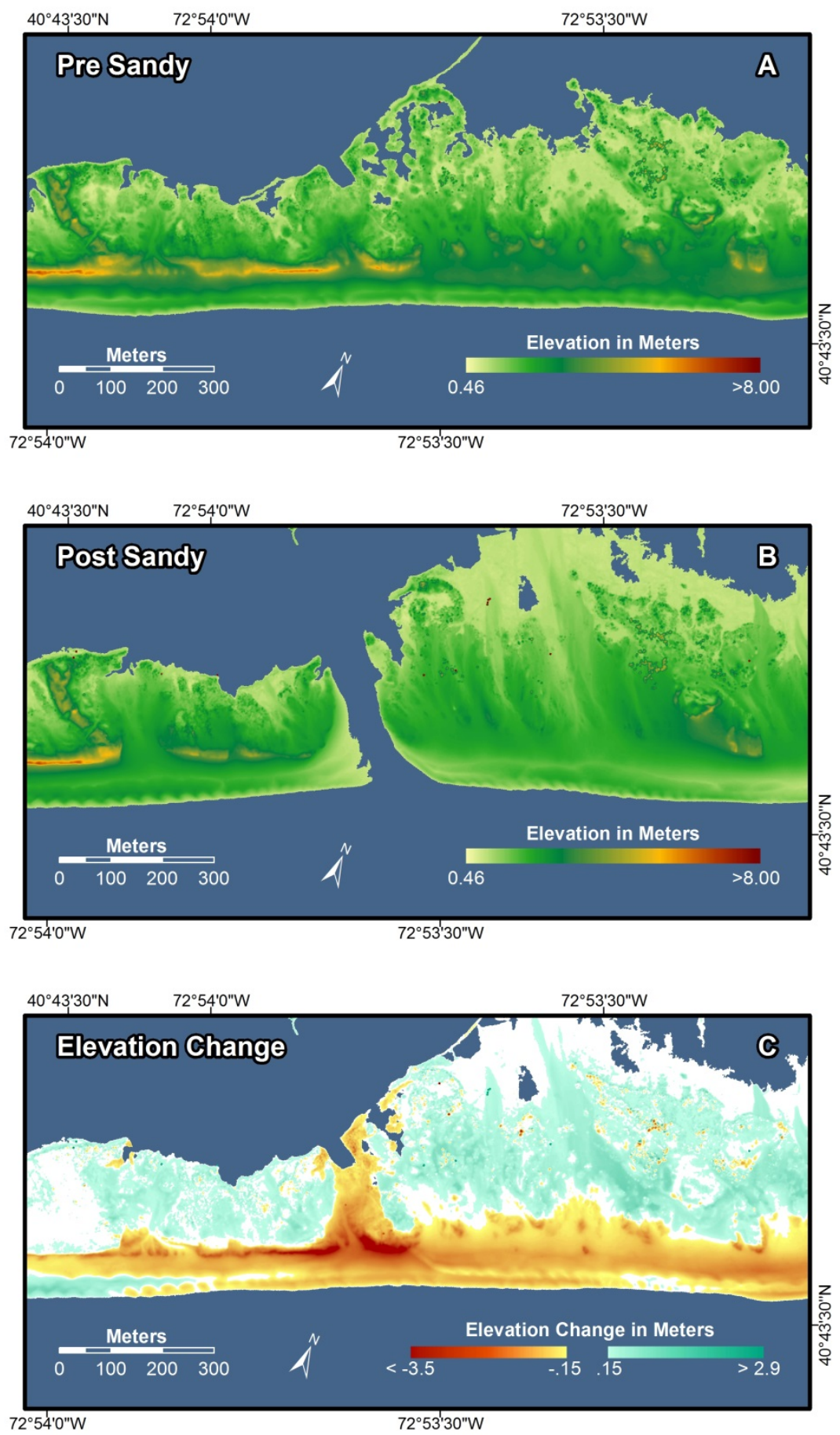

Figure 35. Three-dimensional lidar topography before (May 2012; A) and after (November 2012; B) Hurricane Sandy; and elevation change $(C)$ of location 13 (fig. 8), Pelican Island and Fire Island, New York. This location is within the Fire Island National Seashore near Old Inlet. The island breached during Sandy, creating a new inlet, eroding the beach and cutting through 4-meter- $(\mathrm{m})$ high dunes.

From Moriches Inlet east to Montauk (from $D F L=204-275 \mathrm{~km}$ ), higher dunes (on average 6.6 $\mathrm{m}$ in height) protected much of the coastline from overwash and inundation, and the storm surge threat 
lessened along the eastern portion of Long Island (for example, a peak of approximately $1.8 \mathrm{~m}$ above normal tide was reported at Montauk; Blake and others, 2013) resulting in a mean dune erosion of $1.0 \mathrm{~m}$ (fig. 30A). However, several narrow and low-lying places were breached during the storm including Cupsogue Beach north of Moriches Inlet and W. Scott Cameron Beach south of Mecox Bay $(D F L=240$ $\mathrm{km})$.

The pre-storm lidar elevations used in the coastal-change calculations for this region were acquired during an August 2010 lidar survey for the majority of the New York coast (regions depicted in gray in figure 30; see table 2 for details). On May 7, 2012, the USGS contracted a focused airborne lidar survey of Fire Island, N.Y. These best-available pre-storm data for Fire Island (shown in black in figure 30) were used to calculate coastal-change parameters. A comparison of dune elevation changes on Fire Island, N.Y., between the May 7, 2012, pre-storm survey and the November 5, 2012, post-storm survey (fig. 30), to the dune elevation changes for the same region between the August 2010 pre-storm survey and the November 5, 2012, post-storm survey, indicates that most of the dune erosion that occurred over the intervening two year period was attributable to Hurricane Sandy.

In addition to the USGS contract post-storm lidar survey of Fire Island, N.Y., the post-Sandy elevation data used in calculations of coastal change along the remainder of New York's Atlantic coast were acquired during surveys contracted or carried out by the U. S. Army Corps of Engineers and made publicly available via NOAA Coastal Services Center Digital Coast website (http://www.csc.noaa.gov/digitalcoast/).

\section{Conclusion}

As a part of the National Assessment of Coastal Change Hazards project, the USGS collected post-Hurricane Sandy oblique aerial photography and lidar topographic surveys to document the changes that occurred as a result of the storm. Comparisons of post-storm photographs to those collected prior to Sandy's landfall were used to characterize the nature, magnitude, and spatial variability of hurricane-induced coastal changes. The complete library of pre- and post-Sandy photographs is available online. Analysis of pre- and post-storm lidar elevations were used to quantify magnitudes of change in shoreline position, dune elevation, and beach width. Extensive erosion was observed along the entire study area from North Carolina to New York. Complex spatial variability in the response can be attributed to various factors, including, but not limited to, coastal geomorphology, offshore geology, nearshore processes, and development density. Further analysis of these data will allow for greater understanding of the observed patterns of change. Additionally, the data will also be used to verify the accuracy of pre-landfall coastal-change predictions and refine and improve the models for use in future storms.

\section{Acknowledgments}

The USGS National Assessment of Coastal Change Hazards Project thanks the many scientists and support staff who invested long hours during the 2012 hurricane season. Specifically, we thank our colleagues in the USGS in St. Petersburg; Emily Klipp, Xan Fredericks, Peter Howd, Joe Long, Dave Thompson, Mark Hansen, BJ Reynolds and Jolene Shirley; for their invaluable contributions to the Hurricane Sandy effort. We also thank the EAARL research team (Wayne Wright and Richard Mitchell), Roger Barlow (USGS Geospatial Liaison), and the USGS Water Science Centers in New Jersey and New York for their assistance with data collection. 


\section{References Cited}

Blake, E. S., Kimberlain, T. B., Berg, R. J., Cangialosi, J. P., and Beven, J. L. II, 2013, Tropical cyclone report-Hurricane Sandy: Miami, Fla., National Oceanic and Atmospheric Administration National Hurricane Center, Report AL182012, 157 p. [Also available at http://www.nhc.noaa.gov/data/tcr/AL182012_Sandy.pdf.]

Bonisteel, J.M., Nayegandhi, Amar, Wright, C.W., Brock, J.C., and Nagle, D.B., 2009, Experimental Advanced Airborne Research Lidar (EAARL) data processing manual: U.S. Geological Survey OpenFile Report 2009-1078, 38 p., accessed February 12, 2013, at http://pubs.usgs.gov/of/2009/1078/.

Fanelli, Colleen, Fanelli, Paul, and Wolcott, David, 2013, NOAA water level and meteorological data report-Hurricane Sandy: Silver Spring, Md., National Oceanic and Atmospheric Administration, Center for Operational Oceanographic Products and Services, 62p., accessed April 29, 2013 at http://tidesandcurrents.noaa.gov/publications/Hurricane_Sandy_2012_Water_Level_and_Meteorolog ical_Data_Report.pdf.

Flood, Martin, 2001, Laser altimetry - from science to commercial lidar mapping: Photogrammetric Engineering and Remote Sensing, v. 67, no. 11, p. 1209-1211; 1213-1217.

Hapke, C.J., Himmelstoss, E.A., Kratzmann, M.G., List, J.H., and Thieler, E.R., 2010, National assessment of shoreline change: Historical shoreline change along the New England and Mid-Atlantic coasts: U.S. Geological Survey Open-File Report 2010-1118, 57 p., accessed January 10, 2013, at http://pubs.usgs.gov/of/2010/1118/.

Hapke, C.J., Brenner, Owen, Hehre, Rachel, and Reynolds, B.J., 2013, Coastal change from Hurricane Sandy and the 2012-2013 winter storm season-Fire Island, New York: U.S. Geological Survey Open-File Report 2013-1231, 43 p., accessed September 4, 2013, at http://pubs.usgs.gov/of/2013/1231/.

Kana, T.W., and Kaczkowski, H.L., 2011, Nags Head Beach Nourishment Project (CSE 2203), Final Report - Preliminary Results: Columbia, S.C., Coastal Science \& Engineering, 6 p., accessed April 29, 2011, at http://www.nagsheadnc.gov/vertical/Sites/\%7BB2CB0823-BC26-47E7-B6B637D19957B4E1\%7D/uploads/2011-December_final_report_preliminary_results(1).pdf.

McCallum, B.E., Wicklein, S.M., Reiser, R.G., Busciolano, Ronald, Morrison, Jonathan, Verdi, R.J., Painter, J.A., Frantz, E.R., and Gotvald, A.J., 2013, Monitoring storm tide and flooding from Hurricane Sandy along the Atlantic Coast of the United States, October 2012: U.S. Geological Survey Open-File Report 2013-1043, 42 p., accessed May 1, 2013, at http://pubs.usgs.gov/of/2013/1043/.

National Aeronautics and Space Administration, 2013, Federal Consistency Determination, Wallops Island Post-Hurricane Sandy Beach Renourishment: Wallops Island, Va., National Aeronautics and Space Administration, 28 p., accessed July 29, 2013 at http://sites.wff.nasa.gov/code250/docs/WFF\%20Post\%20Sandy\%20Renourishment\%20FCD\%20FIN AL.pdf. 
National Weather Service Mt. Holly, NJ, 2012, Public Information Statement: Mt. Holly, N.J., 9 p., accessed April 29, 2012 at http://www.erh.noaa.gov/phi/reports/PNSPHI\%202012-11-

01\%200056Z\%20summary\%20rain\%20wind\%20pressure\%20surge.pdf.

Nayegandhi, Amar, Brock, J.C., and Wright, C.W., 2009, Small-footprint, waveform-resolving lidar estimation of submerged and sub-canopy topography in coastal environments: International Journal of Remote Sensing, v. 30, no. 4, p. 861-878. [Also available at http://dx.doi.org/10.1080/01431160802395227.]

North Carolina Department of Transportation, 2012, NCDOT continues damage assessment, clean-up effort from hurricane: Raleigh, N.C., North Carolina Department of Transportation Newsroom, 1 p., accessed May 16, 2013, at https://apps.ncdot.gov/newsreleases/details.aspx?r=7246.

Plant, N.G., Holland, K.T., and Puleo, J.A., 2002, Analysis of the scale of errors in nearshore bathymetric data: Marine Geology, v. 191, nos. 1-2, p. 71-86. [Also available at http://dx.doi.org/10.1016/S0025-3227(02)00497-8.]

Powell, M.D., Houston, S.H., Amat, L.R., and Morisseau-Leroy, Nirva, 1998, The HRD real-time hurricane wind analysis system: Journal of Wind Engineering and Industrial Aerodynamics, v. 77-78, p. 53-64. [Also available at http://dx.doi.org/10.1016/S0167-6105(98)00131-7.]

Retzler, Paula, 2013, Delaware Coast from Cape Henlopen to Fenwick Island, Rehoboth Beach/ Dewey Beach, DE — Rehoboth \& Dewey Beach Coastal Storm Damage Reduction Project: Philadephia, PA, U.S. Army Corps of Engineers Philadelphia District, Marine Design Center, 1 p., accessed April 29, 2011, at http://www.nap.usace.army.mil/Missions/Factsheets/FactSheetArticleView/tabid/4694/Article/6455/delawar e-coast-from-cape-henlopen-to-fenwick-island-rehoboth-beachdewey-beach-de.aspx.

Sallenger, A.H., Krabill, W.B., Swift, R.N., Brock, J., List, J., Hansen, Mark, Holman, R.A., Manizade, S., Sontag, J., Meredith, A., Morgan, K., Yunkel, J.K., Frederick, E.B., and Stockdon, H.F., 2003, Evaluation of airborne topographic lidar for quantifying beach changes: Journal of Coastal Research, v. 19 , no. 1, p. $125-133$.

Stockdon, H.F., Sallenger, A.H., Jr., List, J.H., and Holman, R.A., 2002, Estimation of shoreline position and change using airborne topographic lidar data: Journal of Coastal Research, vol. 18, no. 3, p. 502-513.

Stockdon, H.F., Doran, K.S., and Sallenger, A.H., Jr., 2009, Extraction of lidar-based dune-crest elevations for use in examining the vulnerability of beaches to inundation during hurricanes: Journal of Coastal Research, Special Issue, v. 53, p. 59-65. [Also available at http://dx.doi.org/10.2112/SI53007.1.]

Stockdon, H.F., Doran, K.J., Sopkin, K.L., Smith, K.E.L., and Fredericks, Xan, 2013, Coastal Topography-Northeast Atlantic coast, post-Hurricane Sandy, 2012: U.S. Geological Survey Data Series 765, accessed June 13, 2013, at http://pubs.usgs.gov/ds/765. 
Weber, K.M., List, J.H., and Morgan, K.L.M., 2005, An operational mean high water datum for determination of shoreline position from topographic lidar data: U.S. Geological Survey Open-File Report 2005-1027, accessed January 10, 2013, at http://pubs.usgs.gov/of/2005/1027.

Wozencraft, Jennifer, and Millar, David, 2005, Airborne lidar and integrated technologies for coastal mapping and nautical charting: Marine Technology Society Journal, v. 39, no. 3, p. 27-35. [Also available at http://dx.doi.org/10.4031/002533205787442440.] 
ISSN 2331-1258 (online) http://dx.doi.org/10.3133/ofr20141088 